\title{
EL DESARROLLO HISTÓRICO DEL PRINCIPIO DE LEALTAD FEDERAL EN EL DERECHO ALEMÁN
}

JANIRE MIMENTZA MARTIN 


\section{SUMARIO:}

1. INTRODUCCIÓN. 2. EL ORIGEN DEL PRINCIPIO DE LA LEALTAD FEDERAL EN EL SEGUNDO REICH DE 1871. 2.1. La formación del Segundo Reich alemán: la Constitución de 1871. 2.2. Consejo Federal (Bundesrat): como «tribunal» para la resolución de conflictos (art. 76 I CR). 2.3. Las primeras aproximaciones dogmáticas: TRIEPEL y LABAND. 2.4. La fundamentación dogmática de SMEND en su obra «Derecho Constitucional no escrito en el Estado federal monárquico». 2.5. Aportaciones doctrinales posteriores: ANSCHÜTZ, TRIEPEL y KAUFMANN. 3. EL PRINCIPIO DE LEALTAD FEDERAL EN LA REPÚBLICA DE WEIMAR. 3.1. El alumbramiento de la República: la Constitución de 1919. 3.2. Concreción del principio de la lealtad federal en la Constitución de Weimar. 3.3. Fundamentación dogmática del Bundestreue en la República de Weimar. 3.4. Jurisprudencia sobre el Bundetreue en la República de Weimar. 4. CONCLUSIÓN. 


\title{
EL DESARROLLO HISTÓRICO DEL PRINCIPIO DE LEALTAD FEDERAL EN EL DERECHO ALEMÁN
}

\author{
JANIRE MIMENTZA MARTIN ${ }^{1}$
}

\section{INTRODUCCIÓN}

El conocido principio de la lealtad federal (en adelante también denominado Bundestreue) o «comportamiento favorable a la Federación» (en adelante bundesfreundliches Verhalten), que son lo mismo, presenta una gran tradición en el Derecho público alemán. Básicamente, todo su desarrollo está fundamentado en la doctrina y la jurisprudencia de este país.

Es de destacar, que desde sus orígenes el desarrollo histórico de este principio es de sumo interés. Básicamente, en el centro del análisis histórico del Bundestreue se sitúa a la doctrina y práctica constitucional, que tiene efectos hasta nuestros días. Por ello, los enfoques dados en la Constitución del Imperio Alemán de 1871 y Constitución de Weimar de 1919 son relevantes, porque hoy todavía perduran bajo la Ley Fundamental de $1949 .{ }^{2}$ Su análisis evolutivo ofrece la posibilidad de analizar sus rasgos y cambios a través del tiempo, para finalmente entenderlo en el contexto de nuestro orden Constitucional.

Sorprendentemente en España - al igual que en países anglosajones ${ }^{3}$ - es un tema que se ha tratado con poca profundidad y detalle. ${ }^{4}$ En el caso español los trabajos de

\footnotetext{
1 Profesora de Derecho Constitucional de la Universidad del País Vasco (UPV/EHU). Facultad de Ciencias Sociales y de la Comunicacion. Barrio Sarriena, s/n. 48940 Leioa (Vizcaya). Miembro del Grupo de Investigación Multilevel Constitutionalism and EU Law del Sistema Vasco (IT1380-19). Email: Janire.mimentza@ehu.eus.

2 GADAMER hace hincapié en la necesidad de conocer los orígenes del Bundestreue para entenderlo en la actualidad, dado que sus fundamentos constitucionales históricos siguen hoy vigentes. GADAMER, Hans-Georg (1975). Wabrheit und Methode, Grundzüge einer philosophischen Hermeneutik, 4. edición, Tubinga, Editorial J.C.B. Mohr (Paul Siebeck), p. 283.

FINCK, Michèle (2017). "The Principle of Loyalty in Federations», WOLFRUM, R./ LACHENMANN, F./GROTE, R. (coords.), Max Planck Encyclopaedia of Comparative Constitutional Law, Oxford, Oxford Constitutional Law.

4 Para España únicamente vid. LASO PÉREZ, Javier (2000). «La lealtad federal en el sistema constitucional alemán», Cuadernos de Derecho Público, núm. 9, pp. 47-105; FALLER, Hans-Joachim
} 
derecho comparado en este campo destacan por su ausencia, en especial no existen trabajos sobre su desarrollo histórico. Se aprecia, que es frecuente el uso parcial o incompleto del término «lealtad» en relación a las Comunidades Autónomas con el Estado Central (solidaridad, lealtad constitucional, coerción etc.) sin entrar a analizar su origen y desarrollo histórico. Carencia que posteriormente dificulta entender su alcance. Es precisamente el objetivo de este trabajo el llenar este vacío legal. Teniendo en cuenta que todo orden federal está estrechamente vinculado a las condiciones históricas, políticas, sociales y económicas específicas de su desarrollo histórico, existirá entonces una base para realizar trabajos de derecho comparado. ${ }^{5}$ En definitiva, este trabajo considera que para garantizar el futuro de la investigación multinivel sobre el principio de lealtad federal alemán en España es necesario conocer la doctrina y la práctica judicial desde sus orígenes.

\section{EL ORIGEN DEL PRINCIPIO DE LA LEALTAD FEDERAL EN EL SEGUNDO REICH DE 1871}

La doctrina comparada sitúa el origen del principio de la lealtad federal en los pactos contractuales del Reich alemán entre 1866-1870, que finalmente culminaron con la Constitución del Reich de $1871 .{ }^{6}$ Aunque las referencias más antiguas concretan la fuente histórica de la Bundestreue en el Acta Final de Viena ${ }^{7}$ del 15 de mayo de 1820 , no ha tenido tanta transcendencia.

En base al art. 36 II los Estados particulares no debían lesionar a Estados extranjeros. Pero si ocurría, la Asamblea Federal (Bundesversammlung) exigía la terminación de la acción lesiva, además de un comportamiento leal en defensa de los intereses del Imperio.

\subsection{La formación del Segundo Reich alemán: la Constitución de 1871}

El Imperio alemán del 1871 se formó tras la disolución de la Confederación Germánica. La guerra entre Austria y Prusia y el egoísmo del resto de los Estados en

(1980). «El principio de la lealtad federal en el orden federativo de la República Federal de Alemania», Revista de Estudios Políticos, núm. 16, pp. 197-202; VOGEL, Hans-Jochen (1996). «El Régimen Federal de la Ley Fundamental», BENDA, E./MAIHOFER, W./VOGEL, H.J./HESSE, K./HEYDE, W., Manual de Derecho Constitucional, IVAP, Madrid, Editorial Marcial Pons, pp. 613-675.

5 EGLI, Patricia (2010). Die Bundestreue. Eine rechtsvergleichende Untersuchung, Zurich/St. Gallen, Editorial Dike, p. 19.

6 BAYER, Hermann-Wilfried (1961). Die Bundestreue, Tubinga, Editorial J.C.B. Mohr (Paul Siebeck), p. 3.

7 Wiener-Schluss-Akte. BINDING, Karl (1892). Deutsche Staatsgrundgesetze in diplomatisch genauem Abdrucke: zu amtlichem und zu akademischem Gebrauche, vol. III, Leipzig, Editorial Wilhelm Engelmann, p. 37. 
defensa de su soberanía la disolvió, y acabó con el tratado de paz de Praga en 1866. Desde la desaparición del Sacro Imperio Romano Germánico en 1806 se esperó hasta la victoria de Prusia en 1866 para crear un Estado unido en varias etapas. Tanto el texto constitucional de $1871^{8}$ como su preámbulo se fundamentaban en tratados: los más relevantes fueron la Alianza de agosto de 1866 y la de noviembre de 1870 .

Mediante el primero, el canciller BISMARCK ${ }^{9}$ unió Prusia con quince estados del norte creando la base de Derecho Internacional Público de la Confederación Alemana del Norte de $1867^{10}$ (Norddeutscher Bund). En enero de 1871 mediante los Tratados de adhesión (Novemberverträge) de los Länder del Sur a la Confederación Alemana del Norte, se le unieron cuatro Estados del sur (Baviera, Wurtemberg, Baden y Hesse) creando el Reich alemán. El nuevo Imperio alemán era básicamente una extensión geográfica de la Confederación Alemana del Norte.

Alemania, con la proclamación del Segundo Reich y la Carta Imperial de 1871 formó una Monarquía Federal. ${ }^{11}$ El Imperio alemán era una federación dinástica, semiconstitucional compuesta por gobernantes de los principados alemanes. Fue el privilegio constitucional del Rey de Prusia (Guillermo II) reinar al mismo tiempo como Emperador alemán. ${ }^{12}$ El canciller del Reich (BISMARCK) y su gobierno eran nombrados y respondían ante él.

A pesar de que importantes áreas de la legislación eran competencia del Imperio, gran parte del proceso legislativo, la administración y las finanzas permanecieron bajo los Estados miembros. ${ }^{13}$ El Segundo Reich estaba compuesto por un parlamento bicameral: Cámara baja (Reichstag), y la Cámara alta (Bundesrat).

Se requería la aceptación de ambos para que una ley imperial entrara en vigor. Según el art. 6 de la Constitución del Reich (en adelante CR) el Consejo Federal el (Bundesrat) con sus 58 miembros era el órgano principal en materia legislativa, y además de los mismos derechos que el Reichstag, tenía una prerrogativa de sanción. Es decir, el Bundesrat tenía la potestad de revertir con fuerza un proyecto de ley e intervenía como un «Tribunal de Estado» (art. 76 I CR). Esta era la parte federada

8 Vid. Constitución del Imperio alemán de 16 de abril de 1871, Boletín de Leyes Imperiales, 1871, p. 63 y ss.

9 SCHMIDT, Joachim (1966). Der Bundesstaat und das Verfassungsprinzip der Bundestreue: ein Beitrag zur Lebre vom Bundesstaat unter besonderer Berïcksichtigung des Gedankens der Bundestreue, Wurzburgo, Editorial Universidad de Wurzburgo, p. 8.

10 MAURER, Hartmut (1997). «Entstehung und Grundlagen der Reichsverfassung von 1871», BURMEISTER, J. (coord.), Verfassungsstaatlichkeit, Festschrift für Klaus Stern zum 65. Geburtstag, Múnich, Editorial C.H.Beck, pp. 43 y ss; HUBER, Ernst Rudolf (1988). «Bismarck und das Reich», Deutsche Verfassungsgeschichte seit 1789, vol. III, 3. edición, Stuttgart/Berlin/Köln, Editorial Kohlhammer, pp. 745 y ss.

11 TENORIO SANCHEZ, Pedro Julio (1998). Introducción al Derecho Constitucional Comparado, Madrid, Servicio de Publicaciones de la Facultad de Derecho Universidad Complutense, p. 115.

12 El Primer Ministro prusiano sirvió simultáneamente como canciller imperial. RENZSCH, Wolfgang (1989). «German Federalism in Historical Perspective: Federalism as a Substitute for a National State», The Journal of Federalism, núm. 19, Oxford, Oxford University Press, p. 21.

13 RENZSCH, W. «German Federalism in Historical Perspective...», Op.cit. p. 20. 
de la legislatura: tenía la misma composición que la Asamblea Federal de la Confederación Alemana y era una asamblea de los gobiernos dinásticos de los Estados. Este elemento constitucional estaba destinado a salvaguardar el «principio monárquico»; ; los privilegios políticos de los monarcas y príncipes. Aunque todos los Estados gozaban de la misma soberanía, Prusia era el poder hegemónico del Bundesrat, presidia el Consejo Federal y buscaba acuerdos con los otros Estados más grandes. Como el Consejo Federal en la práctica no posibilitaba alteraciones sustanciales, los Estados más pequeños declaraban su interés en el proceso de negociación política antes de presentar las propuestas al Bundesrat. ${ }^{15}$

El Reichstag era la cámara nacional unitaria, y tenía pocas responsabilidades como votar sobre el limitado presupuesto y los impuestos del Reich. No tuvo ninguna influencia en la composición del gobierno federal, que no era responsable ante el Reichstag. ${ }^{16}$ A pesar de sus limitaciones, la Cámara baja se convirtió en el escenario principal del debate político. ${ }^{17}$

La inicial Constitución de la Confederación fue la base jurídica del nuevo Imperio alemán. Sin embargo, debido a sus frecuentes modificaciones, suplementos y apéndices, se volvió confusa y necesitó una nueva redacción. ${ }^{18}$ La nueva de 1871 no sufrió cambios de contenido, sino que recogió y resumió los acuerdos en un único documento ${ }^{19}$ con él que se solucionaron las inconsistencias terminológicas y la fragmentación de fuentes legales derivadas de la sucesión de tratados.

Es de destacar, que su preámbulo es reflejo de su origen histórico en la que no se presenta a los monarcas como poderes constituyentes, sino como partes contratantes de creación de una «alianza eterna». Se trata de un pacto entre principados con base contractual en virtud de tratados, cuya soberanía no emana de la totalidad de la nación, sino de la voluntad de los Estados soberanos. En definitiva, el titular del poder constituyente no es el pueblo como una unidad, sino sus numerosos príncipes y ciudades libres. ${ }^{20}$

14 RENZSCH, W. «German Federalism in Historical Perspective...», Op.cit., p. 20.

15 RAUH, Manfred (1973). «Föderalismus und Parlamentarismus im Wilhelminischen Reich», Beiträge zur Geschichte des Parlamentarismus und der politischen Parteien, vol. 47, Düsseldorf, Editorial Droste, pp. 50-56.

16 RENZSCH, W. «German Federalism in Historical Perspective...», Op.cit. p. 21.

17 Su importancia creció con el aumento de la legislación nacional económica y social del Imperio. En los años previos a la Primera Guerra Mundial, se convirtió en un importante contrapeso al gobierno del Reich. RAUH, M. «Föderalismus und Parlamentarismus Im Wilhelminischen Reich»..., Op.cit. pp. 50-56.

18 EGLI, P. Die Bundestreue..., Op.cit. p. 23.

19 Vid. MAURER, H. «Entstehung und Grundlagen der Reichsverfassung...», Op.cit. p. 30; HUBER, E.R. «Bismarck und das Reich»..., Op.cit. pp. 745 y ss.

20 HAENEL, Albert (1873). Studien zum Deutschen Staatsrechte. Die Vertragsmässigen Elemente der Deutschen Reichsverfassung, Leipzig, vol. I, Editorial H. Haessel, pp. 92 y ss; MAURER, H. «Entstehung und Grundlagen der Reichsverfassung...», Op.cit. p. 30; HUBER, E.R. «Bismarck und das Reich»..., Op.cit. pp. 745 y ss. 
La fundamentación contractual de la Constitución de 1871 influyó de forma significativa en la práctica jurídica y doctrina. ${ }^{21}$ Mediante esta base se vinculó el término lealtad a las relaciones diplomáticas entre el Imperio y los Länder, que posteriormente desarrolló el principio de lealtad federal. ${ }^{22}$ Esta idea se reflejó en las afirmaciones de BISMARCK y de los gobiernos de cada Estado. Todos ellos interpretaron del preámbulo, que la estructura del Imperio se «asentaba sobre una unión contractual de principados», en el cual los Estados federados se obligaban al cumplimiento de los tratados en base al principio de lealtad federal. ${ }^{23}$

No solo el preámbulo, también en la literatura jurídica se pueden encontrar declaraciones similares, como por ejemplo, en la regulación de la vigilancia imperial (art. $4 \mathrm{CR}$ ): el control sobre las leyes del imperio (art. $17 \mathrm{CR}$ ) y las reglas relativas a la ejecución del Reich (art. 19 CR) eran expresión de «cortesía federal». ${ }^{24}$ No obstante, estas disposiciones no implicaban ninguna obligación explícita de ayuda, respeto mutuo o cooperación. La idea de lealtad federal se reflejaba en el estilo de formular las disposiciones y no en su contenido. Se evitó conscientemente imponer a los Estados miembros y sus dirigentes la obligación de implementar leyes del Reich. Al igual que se evitó que el Reich exigiera su aplicación con frialdad. La redacción de estas disposiciones constitucionales tenía en cuenta que para que los jefes de Estado monárquicos ejecutaran y controlaran las leyes imperiales, el Reich no debía mostrar un «tono imperioso característico del orden policial.» ${ }^{25}$

La estructura constitucional del Imperio difícilmente pudo considerarse como verdaderamente federal y solo gozó de una popularidad limitada. En las áreas predominantemente católicas y entre minorías nacionales, el federalismo era considerado como un medio de defensa contra Prusia y el protestantismo. Por lo que las élites prusianas temían que el federalismo representara una amenaza para la unidad del imperio. Así, los elementos federales de la Constitución, particularmente el Consejo

21 Para conocer más sobre las referencias contractuales de la Constitución del Reich vid. HAENEL, A. Studien zum Deutschen Staatsrechte..., Op.cit. pp. 92 y ss.; KORIOTH, Stefan (1990). Integration und Bundestaat, Ein Beitrag zur Staats- und Verfasssungslehre Rudolfs Smends, Berlin, Editorial Duncker \& Humblot, p. 21; SCHRÖCKER, Sebastian (1966). «Ungeschriebenes Verfassungsrecht im Bundestaat: zum 100. Gründungsjahr des deutschen Bundestaats», Der Staat, vol. V, Berlin, Editorial Duncker \& Humblot, p. 315 y ss.

22 SMEND, Rudolf (1916). «Ungeschriebenes Verfassungsrecht im monarchischen Bundesstaat», Festgabe für Otto Mayer zum siebzigsten Geburtstag dargebracht von Freunden, Verehren und Schülern, Tubinga, Editorial J.C.B. Mohr (Paul Siebeck), p. 259; BAYER, H.-W. Die Bundestreue..., Op.cit. p. 4.

${ }_{23}$ HUBER, E.R. «Bismarck und das Reich»..., Op.cit. p. 788; KORIOTH, S. Integration..., Op.cit. p. 21; BAUER, Hartmut (1992). Die Bundestreue. Zugleich ein Beitrag zur Dogmatik des Bundesstaatsrechts und zur Rechtsverhältnislehre, Tubinga, Editorial J.C.B. Mohr (Paul Siebeck), pp. 41 y ss.

24 SMEND, R. Ungeschriebenes Verfassungsrecht..., Op.cit. p. 266. En lo relativo al art. 4 CR vid. LABAND, Paul (1911). Das Staatsrecht des Deutschen Reiches, vol. I, 5. edición, Tubinga, Editorial J.C.B. Mohr (Paul Siebeck), p. 109.

25 SMEND, R. Ungeschriebenes Verfassungsrecht..., Op.cit. p. 266.

(C) UNED. Revista de Derecho Politico

N. ${ }^{\circ} 109$, septiembre-diciembre 2020, págs. 261-294 
Federal y las prerrogativas de los Estados dinásticos, eran un obstáculo para el cambio hacia la democracia y la libertad. ${ }^{26}$

Para BISMARCK el Reich tampoco era tan federalista como parecía desprenderse del sentido de la Constitución. ${ }^{27}$ La realidad política era más unitaria de lo establecido

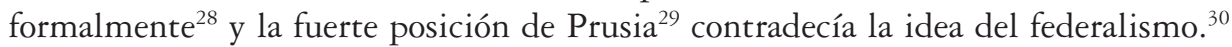
El origen de este Estado Federal fue de naturaleza política. ${ }^{31}$ El canciller abogó en varias ocasiones por la continuación con los tratados como base de la relación federal y en defensa de su lealtad. ${ }^{32}$

\subsection{Consejo Federal (Bundesrat): como «tribunal» para la resolución de conflictos (art. 76 $I C R)$}

Es de destacar, que en el contexto de la Constitución de 1871 intencionadamente no se creó una jurisdicción constitucional en el sentido clásico. El principio de lealtad federal tampoco surgió como una norma justiciable, sino como una expresión legal de acuerdo y cooperación. ${ }^{33}$ Tanto las fuerzas políticas como la doctrina mayoritaria rechazaron la posibilidad de tal jurisdicción por su carácter político. ${ }^{34}$ Sin embargo, se concedió al Consejo Federal (Bundesrat) la potestad de mediar en las disputas constitucionales entre el Imperio y los Estados miembros (art. 76 I CR). ${ }^{35}$

${ }^{26}$ GROSSER, Dieter (1970). «Vom monarchischen Konstitutionalismus zur parlamentarischen Demokratie: Die Verfassungspolitik der deutschen Parteien im letzten Jahrzehnt des Kaiserreiches», Studien zur Regierungslebre und Internationalen Politik, vol. I, La Haya, Springer Netherlands, pp. 101 y ss.

27 ANSCHÜTZ, Gerhard (1924). «Der deutsche Föderalismus in Vergangenheit, Gegenwart und Zukunft», Veröffentlichungen der Vereinigung der Deutschen Staatsrechtslebrer, núm. 1, p. 16.

28 ANSCHÜTZ, G. «Der deutsche Föderalismus...», Op.cit., pp. 11-13.

29 Como Prusia tenía diecisiete votos en el Consejo Federal (art. 6 I CR) podía vetar cualquier reforma constitucional. SCHMIDT, J. Der Bundesstaat und das Verfassungsprinzip..., Op.cit. p. 9.

30 BILFINGER, Karl (1924). «Der deutsche Föderalismus in Vergangenheit, Gegenwart und Zukunft», Veröffentlichungen der Vereinigung der Deutschen Staatsrechtslehrer, núm. 1, pp. 41 y ss.

31 MAYER, Otto (1903). «Republikanischer und monarchischer Bundesstaat», Archiv des öffentlichen Rechts, núm. 18, p. 339.

32 Vid. Más ejemplos MAYER, O. «Republikanischer und monarchischer...», Op.cit. p. 339; SCHRÖCKER, S. «Ungeschriebenes...», Op.cit. pp. 147 y ss; BAYER, H.-W. Die Bundestreue..., Op.cit. pp. 4 y ss; EGLI, P. Die Bundestreue..., Op.cit. pp. 25-26.

33 SMEND, Rudolf (1955). «Ungeschriebenes Verfassungsrecht im monarchischen Bundestaat», Staatsrechtliche Abhandlungen, 1. edición, Berlin, Editorial Duncker \& Humbolt, pp. 39 y ss; SMEND, Rudolf (1928). Verfassung und Verfassungsrecht, Múnich, Editorial Duncker \& Humbolt, pp. 271 y ss. El lector puede encontrar este último trabajo de SMEND en español: SMEND, R. (1985). Constitución y Derecho Constitucional, Madrid, Centro de Estudios Políticos y Constitucionales. Para situar a SMEND y otros iuspublicistas alemanes vid. SOSA WAGNER, Francisco (2005). Maestros alemanes del Derecho Público, Madrid, Editorial Marcial Pons, 2. edición.

34 LABAND, P. «Das Staatsrecht...», Op.cit. pp. 268 y ss; HAENEL, A. Studien zum Deutschen Staatsrechte..., Op.cit. pp. 567 y ss.

35 En este contexto se llegó a definir al Consejo Federal como el Tribunal de garantías constitucionales del Reich («Reichsverfassungsgericht»). HUBER, E.R. (1993). «Die Weimarer 
Como el contenido de la Constitución del Reich de 1871 trataba sobre el funcionamiento de los órganos del Estado fue definida como un «estatuto de organización». ${ }^{36}$ Según Rudolf SMEND el texto Constitucional era excepcionalmente sobrio y poco atractivo, además de estar mal redactado y ser difícil de entender. ${ }^{37}$ Pero curiosamente, este escueto e impreciso documento facilitaba a las fuerzas políticas un amplio margen de interpretación y movimiento. ${ }^{38}$ Así, mientras la Constitución definía la estructura del Estado, su desarrollo y su futuro quedó en manos de los políticos. ${ }^{39}$ Por esta razón, además de estudiar el texto Constitucional, es necesario analizar el funcionamiento de sus órganos e instituciones. ${ }^{40}$

En este contexto, el Consejo Federal (Bundesrat), que es el órgano de representación de los Länder en el Reich, es de especial interés. Este órgano, es un claro ejemplo de cómo la idea de la lealtad federal y contractual - del preámbulo - se extendió en la práctica jurídica del Reich. ${ }^{41}$ Por ejemplo, aunque para llegar a acuerdos se exigía una mayoría simple en el Consejo Federal (art. 7 CR), en la práctica se seguía el principio de unanimidad con un «comportamiento favorable a la Federación» ${ }^{42}$ Este comportamiento («bundesfreundliche Behandlung») 43 obligaba a cerrar acuerdos- incluyendo las reformas constitucionales - mediante el entendimiento, sin tener en cuenta a mayorías. ${ }^{44}$

Así, la idea de la relación contractual favorable al orden federal desarrollado por BISMARCK se manifestó en todo proceso de negociación y toma de decisiones del Consejo Federal. Ante discrepancias entre los Länder se convencía a sus gobiernos mediante concesiones y compensaciones, nunca mediante coacción (art. 19 CR).$^{45}$ En el ejercicio de sus competencias se tenía en cuenta los diferentes intereses de cada

Reichsverfassung», vol. VI, Deutsche Verfassungsgeschichte seit 1789, Stuttgart/Berlin/Köln, Editorial Kohlhammer, pp. 543. Para conocer opiniones en contra, STERN, Klaus (2000). «Die geschichtlichen Grundlagen des deutschen Staatsrechts. Die Verfassungsentwicklung vom Alten Deutschen Reich zur wiedervereignigten Bundesrepublik Deutschland», Das Staatsrecht der Bundesrepublik Deutschland, vol. V, Múnich, Editorial C.H. Beck, pp. 381 y ss.

36 STERN, K. «Die geschichtlichen Grundlagen...», Op.cit. p. 359.

37 SMEND, R. Ungeschriebenes Verfassungsrecht..., Op.cit. p. 266.

38 EGLI, P. Die Bundestreue..., Op.cit. p. 27.

39 Vid. BORNHAK, Conrad (1910). «Wandlungen der Reichsverfassung», Archiv des öffentlichen Rechts, núm. 26, pp. 373-400.

40 STERN, K. «Die geschichtlichen Grundlagen...», Op.cit. p. 360.

41 EGLI, P. Die Bundestreue..., Op.cit. p. 27.

42 BILFINGER, K. «Der deutsche Föderalismus...», Op.cit. p. 67; BAYER, H.-W. Die Bundestreue..., Op.cit. pp. 80 y ss.

43 BILFINGER, K. «Der deutsche Föderalismus...», Op.cit. pp. 113-114.

44 BAYER, H.-W. Die Bundestreue..., Op.cit. p. 5; KAUFMANN, Erich (1917). Bismarcks Erbe in der Reichverfassung, Berlin, Editorial Springer, p. 32.

45 BAUER, Hartmut (2019). «La coerció federal en l'ordenament territorial de la constitució alemanya», Revista Catalana de Dret Públic, núm. 2, p. 6; KAUFMANN, E. Bismarcks Erbe..., Op.cit. p. 32; RITTER VON POSCHINGER, Heinrich (1897). Fürst Bismarck und der Bundesrat, vol. I, Stuttgart/Leipzig, Deutsche Verlagsanstalt, p. 275. 
Estado, actuando como órgano de equilibrio y de comunicación dentro del Reich. ${ }^{46}$ Era evidente, que el Consejo estaba dominado principalmente por los Estados miembros. ${ }^{47}$

Esta función compensatoria y de árbitro fue evidente en el «caso Brunswick», ${ }^{48}$ en el que el Consejo Federal medió con éxito en el conflicto entre el Ducado de Brunswick, Prusia y el Reich. El Ducado pertenecía a la Confederación Alemana del Norte y al Reich. El Duque Georg Wilhelm de Brunswick falleció el 18 de octubre de 1884, y debía de ser sucedido por el Duque de Cumberland.

El problema era que el Duque de Cumberland pertenecía a una casa señorial que no gobernaba en Alemania e hizo demandas territoriales a Prusia sobre Hannover, lo que se vio como un obstáculo para el mantenimiento de las relaciones pacíficas del Bund. ${ }^{49}$ Siendo conscientes de que su coronación conllevaría a un conflicto con Prusia, para garantizar la paz del Imperio se planteó el problema ante el Consejo Federal. Como consecuencia, el Duque de Cumberland anunció la toma de posesión del Ducado y el control del gobierno, pero renunció a su derecho sobre Hannover, que era propiedad de Prusia. El 27 de octubre de 1884 el apoderado de la regencia de Brunswick fue aceptado como el sustituto legal. El Ducado de Brunswick no reguló la sucesión al trono siguiendo sus competencias, sino miró por el interés general de Reich garantizando así la paz interior y exterior. La participación del Consejo en limitar las competencias constitucionales de un Estado en particular, fue expresión del principio de la lealtad federal. ${ }^{50}$ Según SMEND la limitación de competencias en base a la Bundestreue no solo afectaba a los Länder, sino también a la Federación y sus órganos. ${ }^{51}$

Finalmente, mediante invocación al Consejo Federal se estableció el precedente de que cada Estado al ejercer su competencia en la elección al sucesor al trono solo elegiría a candidatos que aceptaran el orden constitucional del Estado en su totalidad, sin poner en peligro los intereses del Reich. Por lo tanto, el Consejo Federal, ejerció la supervisión imperial mediante el entendimiento diplomático, en vez de hacer uso de la fuerza sin contemplaciones. ${ }^{52}$

46 ZORN, Philipp Karl-Ludwig (1895). «Das Verfassungsrecht», Das Staatsrecht des Deutsches Reiches, vol. I, 2. edición, Berlin, Editorial J. Guttentag, p. 169; LABAND, P. Das Staatsrecht...,Op.cit. p. 252.

47 BAUER, H. «La coerció federal...», Op.cit. p. 6

48 Más sobre el caso Brunswick (en alemán Braunchweig) y otros ejemplos vid. SCHRÖCKER, S. «Ungeschriebenes...», Op.cit. pp. 137 y ss; BAYER, H.-W. Die Bundestreue..., Op.cit. p. 7.

49 SCHRÖCKER, S. «Ungeschriebenes...», Op.cit. p. 140; KOWALSKY, Bernd (1970). Rechtsgrundlagen der Bundestreue, Múnich, Editorial Blasaditsch, pp. 8 y ss; DAMBITSCH, Ludwig (1910). Die Verfassung des deutschen Reichs mit Erläuterungen, Berlin, Editorial Franz Vahlen, p. 22.

50 BAYER, H.-W. Die Bundestreue..., Op.cit. p. 112; TRIEPEL, Heinrich (1917). Die Reichsaufsicht, Berlin, Editorial Springer, p. 365; SMEND, R. Ungeschriebenes Verfassungsrecht...,Op.cit. p. 256; DAMBITSCH, L. Die Verfassung..., op. cit. pp. 22 y ss.; KOWALSKY, B. Rechtsgrundlagen..., Op.cit. p. 9.

51 SMEND, R. Ungeschriebenes Verfassungsrecht..., Op.cit. pp. 254 y ss.

52 Ibid. p. 254. 


\subsection{Las primeras aproximaciones dogmáticas: TRIEPEL y LABAND}

Como la Constitución del Reich estaba influenciada por el positivismo jurídico interno, ${ }^{53}$ la doctrina jurídica no estudió sistemáticamente las manifestaciones del principio de lealtad federal. Partiendo de un sistema de normas positivas completas y sin vacíos, la doctrina se concentró en el estudio de cuestiones jurídicas originarias del texto constitucional y construcciones conceptuales derivadas de ella. No se creó un principio general, y como solo se mencionaba en el preámbulo apenas fue objeto de investigación (con la salvedad de algunos preceptos relacionados con la supervisión, control y ejecución de las leyes del Reich). ${ }^{54}$

Recordemos que el Bundestreue jugó un rol importante en la práctica estatal del canciller BISMARCK,${ }^{55}$ quien lo definió como el "principio para el equilibrio político», ${ }^{56}$ que permitió llegar a acuerdos amistosos entre el Imperio y los Estados miembros.

SMEND fue el primero en trasladar su contenido del campo político al jurídico. ${ }^{57}$ Para él, la realidad política debía de estar integrada en la interpretación, lo que le llevó a afirmar la existencia de este principio de Derecho Constitucional no escrito, que dotó de fuerza normativa ${ }^{58}$ (hasta hoy el Tribunal Constitucional Federal lo reconoce remitiendo a la obra de SMEND). ${ }^{59}$ Para los Estados miembros el principio de lealtad contractual y federal era tan importante como el principio de buena fe en el derecho de obligaciones. ${ }^{60}$ Sin embargo, la mayoría de la doctrina iuspublicista del Imperio (Staatsrechtslehre) se posicionó en contra, ya que la práctica de los gobiernos no debía generar consecuencias jurídicas. ${ }^{61}$

En la fase doctrinal anterior a la obra de SMEND existían escasas referencias sobre este principio: caben mencionar las aportaciones de TRIEPEL y LABAND. TRIE-

53 Vid. Más en general BADURA, Peter (1998). Die Methoden der neueren Allgemeinen Staatslebre, 2. edición, Erlangen, Editorial Palm \& Enke, pp. 133 y ss.

54 EGLI, P. Die Bundestreue..., Op.cit. p. 31.

55 BAYER, H.-W. Die Bundestreue..., Op.cit. p. 42; SCHMIDT, J. Der Bundesstaat und das Verfassungsprinzip..., Op.cit. p. 12.

56 BAYER, H.-W. Die Bundestreue..., Op.cit. p. 42.

57 SCHMIDT, J., Ein Beitrag..., Op.cit. p. 13.

58 BRAGUE CAMAZANO, Joaquín (2009). «La doctrina de Smend como punto de inflexión de la hermenéutica y concepción de los derechos fundamentales por los tribunales constitucionales a partir de la segunda posguerral», Revista Iberoamericana de Derecho Procesal Constitucional, núm. 11, p. 99.

59 Sentencias del Tribunal Constitucional Federal alemán (en adelante STCF) que remiten a la obra de SMEND de 1916: STCF 1, 299 (315); 12, 205 (254). Más sobre las sentencias de los primeros pronunciamientos del TCF alemán relativos al principio de la lealtad federal vid. STCF 1, 117 (130 y ss.); 3, 52 (57); 4, 115 (140 y ss.); 6, 309 (361 y ss.); 8, 122 (138 y ss.); 13, 54 (75 y ss.); 14, 197 (214 y ss.); 21, 312 (326); 26, 116 (137); 29, 221 (233); 31, 314, 337 (354 y ss.).

60 SMEND, R. Staatsrechtliche Abhandlungen..., Op.cit. pp. 51-57.

61 Ibid. p. 51. 
$\mathrm{PEL}^{62}$ en su obra de 1907 «Unitarismo y Federalismo» a diferencia de la doctrina positivista de la época hizo referencia a las bases contractuales del Reich. Para él, de la Constitución no derivaban consecuencias jurídicas, sino políticas, y se creó por voluntad de los Estados en base a vínculos contractuales. ${ }^{63}$ Es lo que explicaba su lealtad al Reich. ${ }^{64}$ Según TRIEPEL la obligación de lealtad al Estado en base a tratados era unilateral, solo correspondía a los Estados miembros, y no al revés. ${ }^{65}$

A diferencia de TRIEPEL, LABAND ${ }^{66}$ en su obra de 1911 sobre «El Derecho de Estado del Imperio Alemán», no hizo ninguna referencia a la práctica constitucional de BISMARCK. Sus exposiciones relativas a la obligación de lealtad - siguiendo la corriente positivista - se referían únicamente a la supervisión del Reich (Reichsaufsicht) del art. 4 CR. Según LABAND la función de este órgano era controlar si se cumplía con sus deberes, o si se dañaba mediante conductas de hacer o de no hacer. En definitiva, se controlaba si los Estados miembros cumplían con su obligación de lealtad al Reich. La obligación de obedecer no derivaba directamente de la Constitución, sino de las leyes aprobadas por el Reich. Incluso en campos en los que no se ejercía una potestad legislativa exclusiva, los Estados miembros igualmente quedaban sujetos su control. Como consecuencia, ante la carencia de una ley imperial en cuanto un Estado miembro actuaba contra los intereses del Reich violaba la obligación de lealtad. Tales casos podrían ocurrir al interferir en relaciones del Reich con Estados extranjeros, o estorbar en las relaciones entre los Estados federados, o actuar en contra de las políticas del Reich. LABAND afirmaba que «estos casos graves» no ocurrían con facilidad. ${ }^{67}$ A diferencia de TRIEPEL, LABAND otorgaba a la obligación de lealtad un carácter legal - aunque subsidiario -. Finalmente, los dos autores coincidían en que la los Estados miembros debían velar por los intereses del Imperio, y era de una obligación unidireccional, no existiendo una obligación de lealtad mutua entre los Estados miembros entre sí. ${ }^{68}$

62 TRIEPEL, Heinrich (1907). Unitarismus und Föderalismus im Deutschen Reiche, Tubinga, Editorial J.C.B. Mohr (Paul Siebeck).

63 Opinión coincidente con SMEND, R. Staatsrechtliche Abhandlungen ..., Op.cit. p. 17.

64 TRIEPEL, H. Unitarismus..., Op.cit. p. 29.

65 EGLI, P. Die Bundestreue..., Op.cit. p. 31.

66 LABAND, P. Das Staatsrecht...,Op.cit. p. 109.

67 LABAND, P. Das Staatsrecht..., Op.cit. p. 109.

68 BILFINGER, K. «Der deutsche Föderalismus...», Op.cit. pp. 113-114.

BAUER, H. Die Bundestreue..., Op.cit. pp. 53 y ss.; BAYER, H.-W. Die Bundestreue..., Op.cit. pp. 49 y ss.; KOWALSKY, B. Rechtsgrundlagen..., Op.cit, pp. 23 y ss. 


\subsection{La fundamentación dogmática de SMEND en su obra «Derecho Constitucional no escrito en el Estado Federal Monárquico»}

a) Derecho constitucional no escrito deriva de la interpretación funcional «oculta» en la Constitución de 1871

Fue en 1916 cuando SMEND ${ }^{69}$ publicó la obra jurídica más innovadora sobre el principio de lealtad federal. En su aportación sobre la «Derecho Constitucional no escrito en el Estado Federal Monárquico», SMEND por primera vez justificó dogmáticamente el principio. ${ }^{70}$

SMEND escogió como punto de partida de su investigación el art. 8 III CR, que hacía referencia al Comité de Relaciones Exteriores, compuesto por algunos miembros del Consejo Federal (Bundesrat). Este Comité estaba constituido como un órgano asesor que era informado por la Oficina de Exteriores sobre Política Exterior. ${ }^{71}$ Sin embargo, en sus 35 años de existencia el Comité solo se reunió unas pocas veces. Por lo tanto, constató, que el Reich garantizaba la armonía en política exterior mediante otros medios. ${ }^{72}$ Precisamente por esto, SMEND se interesó por la conciliación de la realidad política con la doctrina positivista. ${ }^{73}$

$\mathrm{Al}$ parecer, con el art. 8 III CR el Comité de Relaciones Exteriores únicamente conseguía «una institución organizativa para obtener una relación funcional entre el Reich y los Estados miembros». Según el principio funcional «oculto» del art. 8 III CR se podían establecer acuerdos en política exterior no solo mediante el Comité de Relaciones Exteriores, sino también por otros instrumentos y medios practicados por el Reich. Según SMEND estas otras formas de informar a los Estados miembros sobre asuntos de política exterior eran «obligaciones constitucionales». ${ }^{74}$

Después de explicar otros ejemplos sobre los derechos y obligaciones de los Estados miembros respecto al Reich, el autor explicó el lenguaje utilizado por la dirección del Reich. Como ejemplo de este uso del lenguaje, SMEND se refirió a BISMARCK, quien en referencia a la base contractual del Reich se autoconsideró «únicamente» como un funcionario de todos los Estados miembros. La decisión fue la misma que la del Comité de Relaciones Exteriores ya mencionado. La declaración sobre la posición canciller como funcionario era solo un encubrimiento de la relación funcional que

69 SMEND, R. Ungeschriebenes Verfassungsrecht..., Op.cit. pp. 245-270.

70 BAUER, H. Die Bundestreue..., Op.cit. p. 56 y ss; UNRUH, Peter (2002), «Die Unionstreue - Anmerkungen zu einem Rechtsgrundsatz der Europäischen Union», Zeitschrift Europarecht, núm. 36, p. 49.

71 EGLI, P. Die Bundestreue..., Op.cit. pp. 32-33. Para conocer más sobre la creación del Comité de exteriores («Bundesratsausschuss») vid. DEUERLEIN, Ernst (1955). Der Bundesratsausschuss für die auswärtigen Angelegenheiten 1870-1918, Ratisbona, Editorial J. Habbel, pp. 26 y ss.

72 SMEND, R. Staatsrechtliche Abhandlungen...,Op.cit. pp. 32-33; SMEND, R. Ungeschriebenes Verfassungsrecht..., Op.cit. p. 251.

73 BAUER, H. Die Bundestreue..., Op.cit. p. 58; KORIOTH, S. Integration..., Op.cit. pp. 46 y ss.

74 SMEND, R. Ungeschriebenes Verfassungsrecht..., Op.cit. p. 252. 
realmente se perseguía. Es decir, el canciller estaba obligado a ejercer su cargo «como si» su puesto no fuera el del primer funcionario de un Estado superior único, sino como un funcionario designado conjuntamente. ${ }^{75}$

En este sentido, los tratados celebrados «darían a la ley estatal un contenido más allá de las disposiciones en el documento constitucional». Por lo tanto, el Imperio y los Estados miembros no solo estarían en una relación de supremacía y subordinación (como sugería la interpretación del contenido esencial de la Constitución), sino en una la relación de gobierno federal con los Estados federados. En consecuencia, de acuerdo con la doctrina mayoritaria, SMEND inicialmente asumió que las relaciones entre el Reich y los Estados miembros se caracterizan por seguir un rango constitucional de supremacía y subordinación. ${ }^{76}$ Sin embargo, complementó esta posición con la idea de que al mismo tiempo el Reich y los Estados miembros compartían en una relación de iguales. A partir de la cual, SMEND concluye que cada uno de los Estados miembros debe lealtad federal y contractual a los demás y al conjunto, ejerciendo sus derechos y obligaciones en este sentido. ${ }^{77}$ En consecuencia, la dirección del Reich en el área del Consejo Directivo Federal no debía actuar siguiendo el espíritu de la supremacía constitucional formal, sino el de lealtad contractual favorable a la federación como entre hermanos aliados. Con ello, el deber del Reich y de los Estados miembros no solo estaría determinado por la Ley constitucional escrita, sino también la no escrita.

b) La fundamentación y la concreción jurídica del contenido de la Bundestreue

SMEND fundamentó los aspectos de lealtad federal observados en las relaciones del Reich y los Estados como ley constitucional no escrita, y añadió que parecía provenir de una combinación de diferentes elementos.

En primer lugar, destacó que el Derecho Constitucional no escrito posibilitaba la interpretación funcional de las normas constitucionales. Mediante esta interpretación, se podían determinar los principios funcionales no mencionados en la norma escrita. ${ }^{78}$ Por otro lado, hay que recordar que los tratados que impulsaron la fundación del Reich todavía estaban vigentes en forma de Derecho no escrito. ${ }^{79}$ Con ellos, la política entendía el texto constitucional con importantes reglas no escritas. ${ }^{80}$ Finalmente,

75 SMEND, R. Ungeschriebenes Verfassungsrecht..., Op.cit. p. 260.

76 Ibid. p. 259. SMEND rechazó explícitamente la teoría de la Escuela de SEYDEL, que consideraba que el Estado federal de Bismarck no era un «Estado» sino una «Federación» basada en tratados entre aliados del mismo rango. Vid. VON SEYDEL, Max (1897). Commentar zur Verfassungs-Urkunde für das Deutsche Reich, 2. edición, Friburgo/Leibzig, Editorial J.C.B. Mohr (Paul Siebeck), pp. 15 y 33.

77 SMEND, R. Ungeschriebenes Verfassungsrecht..., Op.cit. p. 261.

78 Ibid. p. 251.

79 Ibid. p. 261.

80 Ibid. p. 251; BILFINGER, K. «Der deutsche Föderalismus...», Op.cit. pp. 8 y ss. 
SMEND comparó la lealtad federal en relación con el principio de buena fe del derecho de obligaciones. ${ }^{81}$

Respecto a la concreción del contenido del Bundestreue SMEND pone el ejemplo del fenómeno de la lealtad federal, - ya explicado - basado en el art. 8 III CR: es un derecho «oculto» de los Estados miembros a un «contacto regular» en asuntos exteriores para asegurar el establecimiento de acuerdos en política exterior entre la administración imperial y los gobiernos de los Estados miembros.

Además, SMEND mencionó el derecho de cada Estado miembro a seleccionar y nombrar los funcionarios del Reich para garantizar la participación adecuada y proporcionada de todos los estados miembros en el reclutamiento del funcionariado.

SMEND también afirmó que los Estados miembros podían hacer público su posición sobre cuestiones a discutir en el Consejo Federal - a pesar de que los temas a tratar eran confidenciales - para contrarrestar un inminente rechazo en el Consejo Federal.

Además, según SMEND las obligaciones y restricciones de los Estados miembros eran los fundamentos de la lealtad federal. Siendo estos aún más importantes que los derechos de anteriormente mencionados. Ante todo, destacó las limitaciones de los Estados miembros en la configuración de sus propias Constituciones con respecto al Reich.

SMEND también destacó una obligación de los Estados derivado del - ya explicado - caso Brunswick. Esta obligación no escrita forzó a un Estado alemán a renunciar a su legítimo gobernante. Para SMEND tales restricciones de competencias en base al principio de lealtad federal afectaban no solo a los Estados federales, sino también al el gobierno federal y sus órganos. SMEND desarrolló algunas manifestaciones del principio declarando expresamente que estos ejemplos no agotan el alcance de su aplicación. ${ }^{82}$ En general, cada Estado aliado debía lealtad federal a los demás Estados $\mathrm{y}$ al Reich, ejerciendo con ello sus derechos y deberes constitucionales. ${ }^{83}$ Con SMEND, la lealtad federal ganó la importancia de un principio legalmente vinculante ${ }^{84}$ y multifacético para todos los miembros del Estado federal. A diferencia de TRIEPEL ${ }^{85}$ y $\mathrm{LABAND}^{86}$ no se trataba solamente de un obligación legal unilateral, sino el principio se aplicaba en cada una de las relaciones del Estado, incluyendo el Reich.

c) La relación del principio de la lealtad federal con el Estado monárquico

SMEND se ocupó también de la razón y el significado del contenido incompleto y particularidades de la Constitución. ${ }^{87}$ Por un lado, destacó las dificultades técnicas

81 SMEND, R. Ungeschriebenes Verfassungsrecht..., Op.cit. p. 261.

82 SMEND, R. Ungeschriebenes Verfassungsrecht..., Op.cit. p. 258.

83 Ibid. p. 261.

84 BRAGUE CAMAZANO, J. «La doctrina de...», Op.cit. p. 99.

85 TRIEPEL, H. Unitarismus..., Op.cit. p. 29.

86 LABAND, P. Das Staatsrecht...,Op.cit. p. 109.

87 SMEND, R. Ungeschriebenes Verfassungsrecht..., Op.cit. pp. 265 y ss. 
debidas a sus rígidos e inamovibles artículos constitucionales. Resaltó que esta «dificultad» era necesaria, debido a la naturaleza de sus derechos y obligaciones, que entrarían en conflicto con unas normas claras e inequívocas. El principio general de lealtad federal era lo suficientemente elástico para llenar esa «carencia constitucional». 88

Por otro lado, SMEND explicó que la Constitución era incompleta debido a la cortesía federal necesaria de un Estado federal monárquico. Era evidente que no era posible imponer leyes imperiales a los jefes monárquicos. A pesar de que según la Constitución podían ser supervisados por el Reich y forzados a cumplir con sus obligaciones. En definitiva, no se podía tratar a los gobernantes de un Estado monárquico en las mismas formas autoritarias que en un Estado Republicano. El Reich debía dirigirse a ellos según el estilo diplomático del Derecho Internacional y era impensable usar un tono dominante de autoridad superior.

En general, destacó, que la Constitución de un Estado monárquico necesitaba ser completado por el Derecho Constitucional no escrito. ${ }^{89}$ Recordemos que la Constitución escrita fue redactada siguiendo el modelo de Estado Federal republicano. ${ }^{90}$ En definitiva, el principio desarrollado por SMEND se vinculó explícitamente con el Estado federal monárquico.

\subsection{Aportaciones doctrinales posteriores: ANSCHÜTZ, TRIEPEL y KAUFMANN}

Las condiciones marco para una intensa discusión sobre el principio de lealtad federal fueron extraordinariamente difíciles debido al conflicto bélico en la Primera Guerra Mundial y los movimientos revolucionarios internos posteriores..$^{91}$ A esto hay que sumarle que en los últimos años del Reich se hizo evidente una tendencia hacia la centralización. ${ }^{92}$ Sin embargo, la obra de SMEND fue tenida en cuenta por la doctrina mediante las aportaciones de ANSCHÜTZ, ${ }^{93}$ TRIEPEL $^{94}$ y KAUFMANN. ${ }^{95}$

ANSCHÜTZ, ${ }^{96}$ en su primera declaración crítica señaló que el Derecho no escrito de SMEND debía calificarse como Derecho consuetudinario. ANSCHÜTZ destacó que SMEND no aclaró si los fenómenos en que se manifestaba el principio podían ser convicciones legales generales. Pero dado que el derecho no escrito en el sentido de

s8 SMEND, R. Ungeschriebenes Verfassungsrecht...,Op.cit. pp. 266.

89 Vid. BAUER, H. «La coerció federal...», Op.cit. p. 6.

90 SMEND, R. Ungeschriebenes Verfassungsrecht..., Op.cit. pp. 266-269.

91 EGLI, P. Die Bundestreue..., Op.cit. p. 39.

92 Ibid. p. 42.

93 ANSCHÜTZ, Gerhard (1930). «Die Reichtsaufsichts», ANSCHÜTZ, G./THOMA, R. (coords.), Handbuch des Deutschen Staatsrechts, vol. I, Tubinga, Editorial J.C.B. Mohr (Paul Siebeck), p. 367

94 TRIEPEL, H. Die Reichsaufsicht, Op.cit. p. 369.

95 KAUFMANN, E. Bismarcks Erbe..., Op.cit, pp. 31-32.

96 Vid. MEYER, Georg/ANSCHÜTZ, Gerhard (2005). Lebrbuch des deutschen Staatsrechts, 8. edición, Berlin, Editorial Duncker \& Humblot, p. 697 y ss. 
SMEND no pretendía ser Derecho consuetudinario la crítica de ANSCHÜTZ no tuvo éxito. En una obra posterior ANSCHÜTZ ${ }^{97}$ reconoció la existencia de un principio constitucional no escrito por el cual los Estados debían de adaptar su comportamiento a la defensa de los intereses del Imperio.

Aunque TRIEPEL no realizó un estudio detallado del trabajo de SMEND, sí reconoció su enfoque metodológico y el principio en sí. En concreto, su obra sobre «La supervisión del Reich del 1917» metódicamente se parecía al trabajo de SMEND ya que buscaba el sentido funcional del art. $77 \mathrm{CR}$, en vez de su interpretación gramatical. En cuanto el Reich intervenía en el caso de denegación de justicia por parte de algún Estado, se interpretaba según el «sentido perseguido por la ley». Según TRIEPEL los Estados miembros después de «dejar caer la túnica envolvente de la disposición reguladora» del Art. $77 \mathrm{CR}$, debían de abstenerse de su derecho de denegación de justicia. Finalmente, en referencia al estudio de SMEND, añadió, que las obligaciones de los Estados miembros derivadas de otras normas constitucionales representaban Derecho Constitucional no escrito. ${ }^{98}$

Según TRIEPEL, aunque generalmente la supervisión del Reich se limitaba a áreas de su competencia, también se podía ejercer en competencias estatales en conflicto con el Reich, exigiendo a los Estados miembros abstenerse de ejercer sus derechos soberanos. ${ }^{99}$ Como ejemplo de limitación en las competencias de un Estado miembro TRIEPEL destacó ya explicado caso Brunswick sobre la sucesión al trono. Aunque las explicaciones de TRIEPEL no mencionaban explícitamente el término lealtad federal, sí que abordó la obligación de respetar los intereses del Reich. ${ }^{100}$ De igual manera en su anterior obra ${ }^{101}$ TRIEPEL siguió defendiendo que los Estados miembros tenían una obligación unilateral de lealtad al Reich.

Mientras que TRIEPEL solo admitió elementos puntuales del principio de lealtad federal, KAUFMANN en su obra sobre «El legado de Bismarck en la Constitución del Reich» mostró una aceptación general a las teorías de SMEND. KAUFMANN explicó que la conocida frase de BISMARCK «lealtad contractual prusiana» no solo reflejaba el espíritu del momento de la fundación de la Constitución, sino también el de su vigencia. ${ }^{102}$ Como prueba de ello, KAUFMANN citó la organización del Consejo Federal en la que cada Estado tenía como mínimo un voto, lo que daba la oportunidad de participar en las negociaciones de forma igualitaria. Esto se debía a que siguiendo el principio de lealtad federal el Consejo Federal se organizaba en base a un «comportamiento favorable al orden federal».

KAUFMANN también señaló que BISMARCK en sus negociaciones en el Consejo Federal - siguiendo el comportamiento favorable y fiel al tratado - evitaba llegar

97 ANSCHÜTZ, G. «Die Reichtsaufsichts»..., Op.cit. p. 367.

98 TRIEPEL, H. Die Reichsaufsicht, Op.cit. p. 369.

99 Ibid. p. 365.

100 EGLI, P. Die Bundestreue..., Op.cit. p. 41.

101 TRIEPEL, H. Unitarismus..., Op.cit. pp. 29 y ss.

102 KAUFMANN, E. Bismarcks Erbe..., Op.cit. p. 31. 
a acuerdos sobre mayorías, apostando por negociaciones. KAUFMANN defendía también - en la línea de SMEND y BISMARCK - que los principios constitucionales no escritos derivados de los principios contractuales del imperio se aplicaban junto con las normas constitucionales escritas. ${ }^{103}$

\section{EL PRINCIPIO DE LEALTAD FEDERAL EN LA REPÚBLICA DE WEIMAR}

\subsection{El alumbramiento de la República: la Constitución de 1919}

El colapso régimen imperial mediante la revolución de 1918 y el consiguiente establecimiento de un nuevo régimen - apoyado en la Constitución Republicana ${ }^{104}$ - contribuyó a la reorganización de las relaciones entre el Reich y los Estados miembros. ${ }^{105}$ Sobre todo, la tendencia centralista - evidente ya en los últimos años del Segundo Reich - alteró el funcionamiento federal del Estado, aboliendo una gran parte del poder de los Estados y reforzando los componentes unitarios del Estado Federal. ${ }^{106}$

Se vivió una fuerte tendencia centralista en los primeros momentos de la Constitución de Weimar; se excluyó de la toma de decisión de la entrada en vigor de la Constitución a los gobiernos de los Länder, incluyendo a sus parlamentarios. La nueva Constitución fue adoptada por una Asamblea Nacional elegida por el conjunto del pueblo. Por lo tanto, a diferencia del Reich de 1871, los acuerdos en virtud de tratados entre monarcas dejan de ser la base constitucional. En adelante, se aceptaron las decisiones de la Asamblea Nacional que representaba la voluntad de toda la nación. ${ }^{107}$

En definitiva, el nuevo orden constitucional se caracterizó por el fortalecimiento del poder del Reich y la limitación de competencias de los Länder. ${ }^{108}$ Como consecuencia, se hubo cambios significativos en los órganos del Estado. Recordemos, que la Constitución de 1871 otorgaba a cada Länder una posición relevante en los órganos de gobierno del Reich, siendo el Consejo Federal - y no el Reichstag - el órgano supremo del Imperio. Sin embargo, la Constitución de la República de Weimar (en adelante CRW) concedió al Consejo del Reich (Reichsrat) - órgano que sucedió históricamente al Consejo Federal - una posición secundaria con limitadas competencias

103 SMEND, R. Ungeschriebenes Verfassungsrecht..., Op.cit. p. 261.

104 Constitución del Imperio Alemán de 11 de agosto de 1919, Boletín de Leyes Imperiales, 1919, p. 1383.

105 HUBER, E.R. (1978). «Weltkrieg, Revolution und Reichserneuerung 1914-1919», Deutsche Verfassungsgeschichte seit 1789, vol. V, Stuttgart/Berlin/Köln, Editorial Kohlhammer, pp. 1178 y ss.

106 HUBER, E.R. «Die Weimarer Reichsverfassung»..., Op.cit. pp. 59 y ss.

107 BILFINGER, Karl (1923). Der Einfluss der Einzelstaaten auf die Bildung des Reichswillen, Tubinga, Editorial J.C.B. Mohr (P. Siebeck), p. 44; BAYER, H.-W. Die Bundestreue..., Op.cit. p. 14. 108 BILFINGER, K. Der Einfluss der Einzelstaaten..., Op.cit. p. 31. 
administrativas, rebajándolo a ser un subórgano legislativo. A diferencia del Consejo Federal en la Constitución de 1871, el nuevo Consejo del Reich no tenía rol de árbitro en las disputas constitucionales entre los Länder, ${ }^{109}$ por lo que por primera vez en la historia de Alemania se creó un Tribunal estatal, también conocido como la Alta Corte de Justicia. ${ }^{110}$

Como la nueva Constitución se diferenciaba bastante respecto al orden jurídico constitucional monárquico de $1871,{ }^{111}$ el principio se adaptó y desarrolló. Por ejemplo, a diferencia de la anterior, la nueva Constitución Republicana no tenía una base contractual, ${ }^{112}$ habiendo sido este su fundamento hasta entonces. ${ }^{113} \mathrm{La}$ idea de lealtad contractual dejó de ser válida. Sin embargo, en varias disposiciones de la nueva Constitución de 1919 en base a la lealtad federal se incorporaron obligaciones de respeto mutuo, consideración, de apoyo y cooperación. Además, las decisiones del Tribunal de Estado y la doctrina jurídica se refirieron a aspectos del principio de lealtad federal. Como consecuencia, se puede afirmar que la lealtad federal bajo la nueva Constitución se expandió con validez normativa. ${ }^{114}$

\subsection{Concreción del principio de la lealtad federal en la Constitución de Weimar}

Como ya se ha explicado, bajo la Constitución de Weimar no fue posible establecer una conexión con los fundamentos contractuales del Estado federal. Lo justificaba directamente la Asamblea Nacional. ${ }^{115}$ El nuevo fundamento constitucional en el preámbulo de la Constitución de 1919 hacía referencia al «pueblo alemán» (Deutsches Volk), y no a los príncipes soberanos de los Estados miembros.

Aunque en la Constitución de Weimar el preámbulo no servía como punto de partida para la lealtad federal, en otros apartados de la Constitución había disposiciones relacionadas con él. Estas disposiciones creaban obligaciones que se concretaban en tres grupos: a) obligaciones de respeto mutuo, b) obligación de solución pacífica de disputas, y c) obligaciones de información, consulta y participación. ${ }^{116}$ Como se verá a continuación, es de destacar que el texto insiste - con más frecuencia que otras Constitución anteriores - en los intereses de los Länder. ${ }^{117}$

109 EGLI, P. Die Bundestreue..., Op.cit. p. 43.

110 HUBER, E.R. «Die Weimarer Reichsverfassung»..., Op.cit. pp. 542 y ss.

111 Ibid.

112 STERN. K. «Die geschichtlichen Grundlagen...», Op.cit. p. 518.

113 EGLI, P. Die Bundestreue..., Op.cit. p. 44.

114 BAUER, H. Die Bundestreue..., Op.cit. p. 97; BAYER, H.W. Die Bundestreue..., Op.cit. pp. 14 y ss; HUBER, E.R. «Die Weimarer Reichsverfassung»..., Op.cit. pp. 79 y ss.

115 ANSCHÜTZ, Gerhard (1933). Die Verfassung des Deutschen Reichs vom 11. August 1919. Ein Kommentar für Wissenschaft und Praxis. 14. edición, Berlin, Editorial Georg Stilke, pp. 31 y ss.; HUBER,

E.R. «Die Weimarer Reichsverfassung»..., Op.cit. p. 5.

116 EGLI, P. Die Bundestreue..., Op.cit. pp. 45-48.

117 NAWIASKY, Hans (1921). «Der Föderative Gedanke in und nach der Reichsverfassung», Politische Zeitfragen, núm. 3, pp. 140 y ss.; BILFINGER, K. Der Einfluss der Einzelstaaten..., Op.cit. 
a) Obligaciones de respeto mutuo

La competencia para legislar sobre los impuestos y otros ingresos correspondía al gobierno federal (art. 8 CRW). Sin embargo, según el art. 8 II CRW ${ }^{118}$ el Reich debía garantizar la subsistencia de los Estados. Dado que el imperio reclamaba una soberanía financiera ilimitada, en base al art. 8 II CRW debía proporcionar a los Estados los fondos necesarios para su financiación. Como complemento al art. $8 \mathrm{CRW}$, el art. 83 II CRW posibilitó que la administración del Reich creara instituciones para el intercambio de intereses de los Länder en la agricultura, el comercio, y la industria.

Según el art. 16.1 CRW los funcionarios que tuvieran encomendada la administración del Reich en los Länder, deberían ser naturales del mismo. Esto permitía a los Länder garantizar un cierto nivel de representación de sus intereses, y se incorporó además, al texto constitucional la concreción de uno de los postulados de SMEND. ${ }^{119}$

En base al art. 78 I CRW era competencia exclusiva del Reich el cuidado de las relaciones con los Estados extranjeros. Pero según el art. 78 II CRW los Länder podían en áreas de su competencia celebrar tratados con países extranjeros. Éstos debían ser aprobados por el Reich. Por lo tanto, el poder de los Länder quedaba limitado por los intereses y el control preventivo de Reich. ${ }^{120}$ Como consecuencia, el Reich creó instituciones y medidas para garantizar la representación de los intereses de los Estados en sus relaciones con países extranjeros vecinos (art. 78 IV CRW).

Segú el art. 79.2 CRW la «defensa del Imperio era competencia del Reich. Pero la organización militar se reguló de manera homogénea por una ley del Reich teniendo en cuenta las peculiaridades locales». Esta reserva de los Länder fue el resultado de largas negociaciones con los gobiernos estatales de Prusia y los cuatro Estados intermedios de Sajonia, Baviera, Wurtemberg y Baden. Los cinco países estaban de acuerdo con la naturaleza unitaria del sistema de defensa, pero incorporaron el máximo número de instituciones federales posibles para salvaguardar sus intereses.

El respeto a los intereses de los Länder es una expresión «del principio del comportamiento favorable a la Federación» («bundesfreundliches Verbaten») ${ }^{121}$ analizado por SMEND, que obligaba al Reich y los Länder a llegar a acuerdos para la solución de conflictos.

\footnotetext{
pp. 28 y ss.

118 BÜHLER, Ottmar (2010). «Texto de la Constitución alemana de agosto de 1919 y comentario sistemático a sus preceptos», MORTATI, C./JELLINEK, W./BÜHLER, O. La Constitución de Weimar, Madrid, Editorial Tecnos, p. 163.

119 SMEND, R. Ungeschriebenes Verfassungsrecht..., Op.cit. pp. 252 y ss.

120 ANSCHÜTZ, G. Die Verfassung..., Op. cit. p. 418.

121 Vid. SMEND, R. Verfassung..., Op.cit. pp. 172 y ss.
} 
b) Obligación de solución pacífica de disputas

La Constitución también preveía la obligación de solución pacífica de disputas. Por ejemplo, según el art. 15 III CRW en relación al art. 19 CRW, ${ }^{122}$ en caso de disputas entre el Reich y los Estados federales existía la obligación de actuar con un «comportamiento favorable a la federación» («bundesfreundlichen Verfabren»). ${ }^{123}$ Como consecuencia, se estableció - como indicaba SMEND - la obligación de dar una solución extrajudicial a los desacuerdos entre el Bund y los Estados miembros o éstos entre sí. ${ }^{124}$

En definitiva, las controversias sobre cuestiones constitucionales entre Estados federales se resolverían con base en un «procedimiento favorable a la federación», incluyendo por ejemplo el inicio de negociaciones sobre participación en conflictos. Es decir, la intervención del Reich en situaciones de excepción - conocido como la ejecución del Reich (art. 48 CRW) - sería la última ratio.

c) Obligaciones de información, consulta y participación

En este contexto, es de destacar el art. 67 CRW sobre la participación en la administración del Reich. En base a él, los Ministerios debían tener al corriente sobre la marcha de los asuntos del Imperio al Consejo del Reich (Reichsrat). Además, al deliberar sobre asuntos de importancia los Ministerios deberían consultar a sus Comités.

Esta disposición representaba el deber que SMEND describió como la obligación de contacto regular entre el gobierno federal y los Estados miembros. ${ }^{125}$ En realidad el art. 67 CRW representaba una práctica originaria de la Constitución del Reich en 1871, con el objetivo garantizar un intercambio de información constante, y la participación de los órganos federales en los asuntos del gobierno del Reich. Sin embargo, en la Constitución de Weimar las dos obligaciones se trasladaron niveles ministeriales.

Además, el Reich en el ejercicio de sus competencias en el área de la gestión de transporte también tenía la obligación de consultar a los Länder. ${ }^{126}$ En concreto, al tratar sobre el monopolio de los ferrocarriles del Reich (art. 94 I 2 CRW), y al regular la apropiación de las vías navegables por el Reich (art. 97.3 CRW).

Así, según el art. 94 I 2 CRW, si al construir o rectificar una nueva instalación se afectara a la esfera de competencia de autoridad policial de un Land, la administra-

122 En este contexto el art. 15.3 CRW trataba sobre la inspección del Reich sobre los Länder, mientras que el art. 19 CRW trataba sobre los litígios constitucionales del Tribunal de Estado.

123 SMEND, R. Verfassung..., Op.cit. p. 172 y ss.

124 Ibid.

125 SMEND, R. Verfassung..., Op.cit. p. 250.

126 EGLI, P. Die Bundestreue..., Op.cit. p. 48. 
ción de los ferrocarriles del Reich debía escuchar a las autoridades del Land. En consecuencia, cuando las actividades afectaran a los intereses policiales, el Reich debía dar la oportunidad de expresar su opinión. En tal caso, la administración ferroviaria debía proporcionar a la autoridad del Land los documentos necesarios para una evaluación exhaustiva de las necesidades de la policía. ${ }^{127}$

Igualmente, en base al art. 97 III CRW al administrar y ampliar nuevas construcciones de vías navegables debían de tenerse en cuenta las necesidades de la cultura campestre y el régimen de aprovechamiento de aguas de los Länder. Esta disposición debía entenderse de tal manera que el Reich, incluso siendo el único responsable en materia de vías fluviales, necesitaba la aprobación del Land, siempre que la medida afectara a los intereses del territorio y la gestión sus aguas. ${ }^{128}$

\subsection{Fundamentación dogmática del Bundestreue en la República de Weimar}

a) Continuación de las teorías de lealtad federal de SMEND en su obra «Constitución y Derecho Constitucional»

Como se ha explicado la Constitución de 1919 mostraba diferencias significativas respecto al orden jurídico constitucional monárquico anterior, contexto en que SMEND fundamentó el principio de lealtad federal en su obra «Derecho Constitucional no escrito en el Estado federal monárquico».

El principio se cuestionó bajo la nueva Constitución, por lo que sus bases doctrinales tuvieron que adaptarse a las nuevas circunstancias. SMEND admitió diferencias, aclarando que la fuente constitucional legítima de la Constitución del Reich de 1871 residía en las «individualidades estatales legítimas históricamente», mientras que en la Constitución de Weimar en la «legitimidad democrática del todo». ${ }^{129}$ En la época de Weimar se rechazó expresamente la idea de la monarquía en su art. 1 I CRW afirmando que la Constitución era la base de una República. En el nuevo contexto sus críticos alegaron que el principio no era aplicable bajo la nueva forma de Estado, ya que SMEND lo había desarrollado exclusivamente para un Estado monárquico.

La Constitución de 1919 también rechazó cualquier vínculo de base contractual, ya que su preámbulo manifestaba que la Constitución era expresión de la voluntad del pueblo y no de alianzas entre diferentes monarcas. ${ }^{130}$ En este contexto había una línea doctrinal que afirmaba que como la República habían definido todos los derechos y obligaciones entre el Reich y los Länder los principios constitucionales no escritos de

127 GEBHARD, Ludwig (1932 ). «Comentario al art. 94 CRW», Handkommentar zur Verfassung des Deutschen Reiches vom 11. August 1919, Múnich/Berlin/Leipzig, Editorial J. Schweitzer.

128 GEBHARD, L. «Comentario al art. 97 CRW ...», Op.cit.

129 SMEND, R. Verfassung..., Op.cit. p. 168.

130 THOMA, Richard (1930). «Das Reich als Bundestaat», ANSCHÜTZ, G./THOMA, R. (coords.), Handbuch des Deutschen Staatsrechts, vol. I, Tubinga, pp. 170 y ss.; ANSCHÜTZ, G. Die Verfassung..., Op. cit. pp. 31 y ss. 
SMEND eran innecesarios. ${ }^{131}$ BEHNKE añadió, que de una Constitución a otra se había pasado de la semi-oscuridad de la influencia legal y política de los Estados miembros en el poder imperial, a otro Estado con relaciones legales claras entre los Länder y el Reich. ${ }^{132}$

No obstante, SMEND en su obra «Constitución y Derecho Constitucional» hizo referencia explícita a la vigencia del principio de lealtad federal bajo la nueva Constitución. Según él, la doctrina relativa a la obligación suprema de comportarse con lealtad federal entre el Estado Federal y sus miembros no se limitaba al derecho de un Estado monárquico, sino seguía vigente bajo la República de Weimar. ${ }^{133}$

Para SMEND la integración de los Länder en el conjunto del Reich era lo esencial, y rechazó enfoques formalistas que permitían a los Länder competencias constitucionales para usos egoístas e irresponsables. ${ }^{134}$ La Constitución obligaba a las dos partes a además del correcto cumplimiento de las obligaciones - incluyendo garantías procesales como la Comisión de control o Tribunal Estatal -, a crear favorables y buenas relaciones a la Federación. ${ }^{135}$

Destacó en su estudio, que el fundamento básico del principio de la lealtad federal era la propia estructura del Estado Federal, que consistía en el orden entre los Länder y el Reich. SMEND relacionó ésta fundamentación estructural con una argumentación teleológica. Sobre la que añadió que la función principal de la Constitución era la integración del Reich y de los Länder en la totalidad del Estado. Basada en la doctrina integradora, el Reich y los Länder disfrutaban de competencias como parte de un compromiso político de mayor envergadura. ${ }^{136}$

b) Posicionamiento de la doctrina jurídica en la República de Weimar: ANSCHÜTZ y BILFINGER

La idea promovida por SMEND de que el principio no escrito de lealtad federal también tenía vigencia bajo la Constitución de Weimar fue confirmada por muchos iuspositivistas de renombre. ${ }^{137}$ Su expresión máxima fue el uso del principio de lealtad

131 EGLI, P. Die Bundestreue..., Op.cit. p. 59.

132 BEHNKE, Kurt (1926). Die Gleicheit der Länder im deutschen Bundestaatsrecht: Eine staatsrechtliche Studie auf rechtsvergleichender Grundlage, Berlin, Editorial Struppe \& Winckler, p. 66.

133 SMEND, R. Verfassung..., Op.cit. p. 168.

134 Ibid. p. 170.

135 Ibid. p. 171.

136 SMEND, R. Verfassung..., Op.cit. p. 171; KORIOTH, S. Integration..., Op. cit. pp. 111 y ss.

137 Para conocer algunos de ellos vid. JELLINEK, Walter (1925). «Verfassung und Verwaltung des Reiches und der Länder», Leipzig/Berlin, Teubners Handbuch der Staats -und Wirtschaftskunde, vol. II, Leipzig, Editorial B.G. Teubner, pp. 24 y ss.; THOMA, R. «Das Reich als Bundestaat»..., Op.cit. pp. 184 y ss.; ANSCHÜTZ, G. Die Verfassung..., Op. cit. p. 272; ANSCHÜTZ, G. (1930). «Die Reichtsexekution», ANSCHÜTZ, G./THOMA R. (coords.), Handbuch des Deutschen Staatsrechts, vol. I, Tubinga, Editorial J.C.B. Mohr (Paul Siebeck), p. 378; TRIEPEL, H. (1923). «Streitigkeiten zwischen Reich und Ländern», Festgabe der Berliner juristischen Fakultät für Wilhelm Kabl zum Doktorjubiläum am 
federal por los expertos del Tribunal de Estado en el «caso Preussenschlag,» ${ }^{138}$ que fue aceptado sin excepción entre los expertos del Derecho, diferenciándose únicamente en su ámbito de aplicación. Por lo tanto, se puede afirmar que en el período de Weimar el principio de lealtad federal se concentró y obtuvo vigencia normativa. ${ }^{139}$ En concreto, la idea de lealtad al gobierno federal se discutió en profundidad en el trabajo de ANSCHÜTZ y BILFINGER.

Después de las críticas iniciales al enfoque de SMEND, ANSCHÜTZ reconoció los principios generales no escritos de la estructura de los Länder en su Comentario sobre la Constitución de Weimar y en su descripción sobre la supervisión del Reich. ${ }^{140}$ Simplemente apoyado en sus explicaciones relativas a la supervisión del Reich llegó a la conclusión que se extendía también a áreas de competencia de los Länder. De acuerdo con el art. 15 I CRW el gobierno del Reich ejerció la supervisión en asuntos en los que el Reich tenía derecho a legislar, no pudiendo supervisar en áreas de competencia de los Länder. Para ANSCHÜTZ esta conclusión era errónea, ya que la supervisión del Reich también se extendía a competencias reservadas a los Länder. Limitó la supervisión a algunas infracciones de los Länder, y a los principios constitucionales del Reich.

En opinión de ANSCHÜTZ, los Länder en el ejercicio de sus competencias debían defender los intereses del imperio en áreas bajo la jurisdicción del Reich en las que no habían actuado. Los Länder debían tener en cuenta la totalidad de los intereses del Reich. ${ }^{141}$ Estos no podían infringir la política exterior del Reich mediante acciones u omisiones. En el art. 48 I CRW sobre la Ejecución del Reich había explicaciones análogas a los comentarios de ANSCHÜTZ: se activaba la ejecución del Reich cuando un Länder no cumplía con sus obligaciones. Según ANSCHÜTZ las obligaciones exigibles al Reich del art. 48 I CRW no tenían basarse explícitamente en una disposición constitucional o legal.

Para ANSCHÜTZ, basado en SMEND, el principio de deber de lealtad de los Länder era un principio legal no escrito de la Constitución. Estaba de acuerdo con SMEND en la medida en que fundamentaba la estructura constitucional del Estado, incluyendo la estructura de los Länder dentro y para el Reich ${ }^{142}$ siguiendo el sentido de la constitución e idea del Reich. ${ }^{143}$

19. April 1923, Tubinga, Editorial J.C.B. Mohr (Paul Siebeck), pp. 72 y ss; SCHÜLE, Adolf (1932). «Das Problem der Einstweiligen Verfügung in der Deutschen Reichsstaatsgerichtsbarkeit», Beiträge zum ausländischen öffentlichen Recht und Völkerrecht, núm. 19, Publicaciones del Instituto Max Planck de Derecho Público Comparado y Derecho Internacional, Berlin, Editorial Heymanns, p. 117 y ss.

138 Explicado en el apartado 3.4.b de este trabajo.

139 BAUER, H. Die Bundestreue..., Op.cit. p. 97; BAYER, H. W. Die Bundestreue..., Op.cit. pp. $14 \mathrm{y}$ ss.

ANSCHÜTZ, G. Die Verfassung..., Op. cit. p. 114.

Ibid. p. 369.

142 Ibid. p. 114.

143 Ibid. p. 272; ANSCHÜTZ, G. «Die Reichtsexekution»..., Op.cit. p. 378. 
Sin embargo, a diferencia de SMEND, ANSCHÜTZ reconocía el principio no escrito de lealtad federal únicamente como obligación de los Länder y no del Reich. En base a esta reflexión, se apreciaban paralelismos con los trabajos sobre la Constitución del Reich de 1871 de LABAND $^{144}$ y TRIEPEL, ${ }^{145}$ en el que únicamente reconocieron la obligación de unilateral de lealtad de los Länder.

El examen del enfoque SMEND fue promovido significativamente por BILFINGER en su reconocido estudio de 1923 sobre «La influencia de los Estados miembros en la formación de la voluntad del Reich». Al inicio de su obra BILFINGER aclaró que a la hora de examinar un problema no era suficiente una consideración puramente formal de las normas constitucionales. ${ }^{146}$ Más bien se tendrían que examinar los hechos reales de significativa influencia de los Länder en la formación de la voluntad del Reich. En este sentido BILFINGER admitió sentirse conectado con el método y en parte también con la tendencia del primer trabajo de SMEND sobre el «Derecho Constitucional no escrito en el Estado monárquico». ${ }^{147}$

Según BILFINGER bajo la Constitución de Weimar seguiría existiendo una «alianza constitucional general», ${ }^{148}$ en base al cual la continuación del principio de pacto en el pensamiento federal seguía vigente en las dos Constituciones. No precisamente por su base contractual, sino por la continuación real de las relaciones históricas. ${ }^{149} \mathrm{El}$ concepto legal de alianza se entendió como un principio constitucional no escrito, y se expresó en algunas disposiciones constitucionales aisladas, por las que el Reich debía considerar los intereses de los Estados miembros. ${ }^{150}$ Por otro lado, BILFINGER - al igual que SMEND - negó que el fundamento del principio fuera la base contractual del Reich de 1871, sino era la estructura u organización federal del Reich. ${ }^{151}$ Afirmó que el principio de alianza y sus diferentes aspectos eran consecuencia de la estructura y organización federal del Imperio. ${ }^{152}$ Finalmente, los casos individuales observados en la práctica legal, y ciertas disposiciones individuales de la ley constitucional escrita lo confirmaron. ${ }^{153}$

\subsection{Jurisprudencia sobre el Bundetreue en la República de Weimar}

La creación del Tribunal de Estado del Reich alemán (Staatsgerichtshof), posibilitó solucionar las disputas entre la Federación y los Estados federados. A diferencia del

144 Vid. LABAND, P. Das Staatsrecht..., Op.cit. p. 109.

45 Vid. TRIEPEL, H. Unitarismus..., Op.cit. pp. 29 y ss.

46 BILFINGER, K. Der Einfluss der Einzelstaaten..., Op.cit. p. 9.

147 BILFINGER, K. Der Einfluss der Einzelstaaten..., Op.cit. p. 8.

148 Ibid. pp. 55-57; SCHÜLE, A. «Das Problem der Einstweiligen Verfügung ...», Op. cit. p. 58.

149 BILFINGER, K. Der Einfluss der Einzelstaaten..., Op.cit. p. 44.

150 EGLI, P. Die Bundestreue..., Op.cit. p. 64.

151 BILFINGER, K. Der Einfluss der Einzelstaaten..., Op.cit. pp. 8 y ss.

152 Ibid. p. 58.

153 Ibid. 
Consejo Federal del Reich de 1871 el nuevo Reichsrat de la República de Weimar no ejercía de árbitro, ${ }^{154}$ en su lugar se acudía al Tribunal de Estado del Reich. ${ }^{155}$ Por primera vez en la historia constitucional alemana, la creación de éste tribunal ${ }^{156}$ posibilitó solucionar las disputas entre el Reich y los Länder, y éstos últimos entre sí mediante sentencias judiciales.

Según el art. 19 CRW a solicitud de una de las partes, el Tribunal de Justicia del Estado decidía sobre disputas constitucionales de los Länder sin tribunal propio. Baviera, Wurtemberg, Turingia, Hesse y Hamburgo, Mecklenburgo-Schwerin y Oldenburgo tenían sus propios Tribunales, aplicándose para el resto de los Länder el art. 19 CRW. Aunque su jurisprudencia no hizo referencia explícita al concepto del principio de lealtad federal, el Tribunal si sostuvo argumentos con expresión de este principio. ${ }^{157}$

a) El principio de lealtad federal en la relación de los Länder entre sí: ej. caso del hundimiento del Danubio («Donauversinkung»)

En un primer momento, la idea de la obligación de lealtad federal se proyectó en los juicios entre los diferentes Länder. Así en el proceso de Bremen contra Prusia se hizo referencia a la cláusula rebus sic stantibus en relación a un convenio entre Län$\operatorname{der}^{158}$ basado en las obligaciones de respeto mutuo derivados de la relación federal. Hasta el 26 de mayo de 1905 se celebraron dos tratados, que incluían la expansión del puerto y las instalaciones en Bremerhaven y el intercambio acordado áreas terrestres y acuáticas. Sin embargo, en base a las cláusulas contractuales las áreas asignadas a Bremen solo podían ser usadas de una forma específica. Bremen argumentó contra la validez de esta cláusula restrictiva argumentando que era posible anularla «si el interés general o el interés imperativo de una parte lo requiriese». ${ }^{159}$ Bremen también señaló que los conflictos armados que habían tenido lugar desde la firma del convenio habían derivado en un cambio significativo en las circunstancias. ${ }^{160}$

Del mismo modo, el Tribunal Estatal de Justicia en su sentencia de 29 de junio de 1925 reconoció que los Convenios entre Länder se podían anular en base al prin-

154 EGLI, P. Die Bundestreue..., Op.cit. p. 43.

155 HUBER, E.R. «Die Weimarer Reichsverfassung»..., Op.cit. 542 y ss.

156 El denominado Tribunal de Estado ejercía en la práctica las funciones de un Tribunal Constitucional para resolver conflictos entre la Federación y sus Estados miembros. Vid. BAUER, H. Die Bundestreue..., Op. cit. pp. 66 y ss.

157 EGLI, P. Die Bundestreue..., Op.cit. p. 49.

158 Es de destacar, que en el Derecho Público alemán hay tratados intrafederales entre los Länder.

159 Esta demanda surgió de la fusión de los Länder en el Reich, que implicaba «que una parte debía tener en cuenta los intereses vitales de la otra parte». LAMMERS, Hans-Heinrich/SIMONS, Walter (1933). Die Rechtssprechung des Staatsgerichtshofs für das Deutsche Reich und des Reichtsgerichts auf Grund Artikel 13 Absatz 2 der Reichsverfassung, vol. I, Berlin, Editorial Stilke, p. 200.

160 LAMMERS, H.-H./SIMONS, W. Die Rechtssprechung..., vol. I, Op. cit. pp. 200 y ss. 
cipio de clausula rebus sic stantibus. Después de presentar su opinión sobre la cláusula rebus sic stantibus, el Tribunal de Estado declaró que la validez del principio en el Derecho Internacional público no significaba que automáticamente se pudiera aplicar en el Derecho de Estado. La sentencia el Tribunal Estatal no llegó a detallar las diferencias en la obligación de respeto mutuo en el Derecho Internacional Público y el Derecho de Estado. Finalmente, el Tribunal desarrolló y explicó la diferencia entre las dos disciplinas en el caso del hundimiento del Danubio «Donauversinkung» del 18 junio $1927 .{ }^{161}$

Se trataba de un litigio entre el Land Baden contra los Länder Wurtemberg y Prusia. ${ }^{162}$ La bajada del nivel del agua, que beneficiaba a la primera región, perjudicaban a las otras dos. Por lo que Baden tenía un gran interés en el hundimiento para con ello suministrar agua a su industria y población, en perjuicio de Wurtemberg y Prusia. Ambos Länder defendían que Baden había provocado las pérdidas de agua del Danubio a través de ciertas medidas y solicitaron al Tribunal del Estado que Baden debía garantizar con más cuidado el mantenimiento del flujo del agua. ${ }^{163}$ Baden se defendió con el argumento que había cambios geológicos por corrientes naturales, y que el Wurtemberg había provocado cambios en la zona del hundimiento que después le perjudicaron.

Para cerrar el vacío legal el Tribunal de Estado hizo referencia a la mencionada sentencia del 29 junio 1925 inspirada en principios del Derecho Internacional Público. La Alta Corte de Justicia señaló que el Derecho Internacional Público se basaba esencialmente en la idea de restringir la soberanía territorial de los Estados a través de su pertenencia a la comunidad de Derecho Internacional. De esta idea del Derecho Internacional Público derivaba el «deber de los Estados de respeto y consideración mutuo». ${ }^{164}$ A ello, el tribunal respondió que la comunidad de los Länder dentro del Reich, tenía una relación más estrecha. Añadiendo que este tipo de relación conducía a una restricción más fuerte del principio de soberanía territorial que cuando se trataba de dos estados completamente extranjeros. ${ }^{165}$

Las declaraciones del Tribunal del Estado podían entenderse de manera que, el Tribunal a la hora de llenar los vacíos se basada en el Derecho Constitucional no escrito, ${ }^{166}$ que se fundamentaba en la «cercana relación» de los Länder como miembros del Reich. ${ }^{167}$ A partir de la idea de la comunidad el Tribunal del Estado desarrolló

61 EGLI, P. Die Bundestreue..., Op.cit. p. 50.

162 LAMMERS, H.-H./SIMONS, W. Die Rechtssprechung..., vol. I, Op. cit. pp. 178 y ss; BLECKMANN, Albert (1973). «Völkerrecht im Bundestaat?, Gedanken zum Zweiten Coburg-Urteil des Bundesverfasungsgerichts vom 30. Januar 1973», Schweizerisches Jabrbuch für internationals Recht, núm. 29, p. 33.

163 LAMMERS, H.-H./SIMONS, W. Die Rechtsprechung..., vol. I, Op. cit. pp. 181-182.

164 LAMMERS, H.-H./SIMONS, W. Die Rechtssprechung..., vol. I, Op. cit. p. 186.

165 Ibid.pp. 187 y 211.

166 EGLI, P. Die Bundestreue..., Op.cit. p. 52.

167 LAMMERS, H.-H./SIMONS, W. Die Rechtssprechung..., vol. I, Op. cit. p. 187.

(C) UNED. Revista de Derecho Politico

N. ${ }^{\circ} 109$, septiembre-diciembre 2020, págs. 261-294 
una obligación legal entre los Länder «de no dañar al Land vecino y a tener en cuenta sus intereses», un deber equivalente al principio de lealtad federal. ${ }^{168}$

Los pronunciamientos se confirmaron en la decisión del tribunal del 9 de junio de 1928. ${ }^{169}$ Bremen en su demanda contra Prusia, Turingia y Brunswick, afirmó que el rio Weser estaba muy contaminado por las aguas residuales de la industria de los otros Länder, y que su agua ya no era potable ni adecuada para su uso. En consecuencia, Bremen solicitó que Prusia, Turingia y Brunswick tomaran medidas para prevenir la contaminación con base a la «obligación legal federal de los Länder siendo miembros del Reich de tener en cuenta los intereses vitales de otro Land». ${ }^{170}$ Mediante esta sentencia el Tribunal de Estado admitió aceptar casos en los que un Land utilizaba su soberanía en contra de otro en contraposición con los derechos y obligaciones del Imperio. ${ }^{171}$ Además, el Tribunal de Justicia confirmó los argumentos ya expresados en el caso del hundimiento del Danubio (Donauversinkung), en el que la relación de las dos partes «la soberanía territorial debería entenderse más restrictiva, que si dos estados extranjeros se enfrentaran entre sí». ${ }^{172}$

b) El principio de lealtad federal en la relación del Reich con los Länder: ej. caso del golpe a Prusia («Preussenschlag»)

Es caso del golpe a Prusia, («Preussenschlag») entre el Reich y Prusia de 1932 fue el litigio de Estado más significativo de toda la era de Weimar. ${ }^{173}$

El trasfondo de este caso fue que después de las elecciones estatales prusianas en abril de 1932, con nacionalsocialistas y comunistas con la mayoría de votos, no se pudo formar un gobierno estable. Como consecuencia, el Presidente del Reich (VON HINDENBURG) - apoyado en un Decreto ${ }^{174}$ - colocó al canciller conservador (VON PAPEN) como Comisario del Reich en Prusia. El canciller VON PAPEN el mismo día despidió a los miembros del gobierno prusiano, y se hizo cargo junto con algunos

168 BLECKMANN, A. «Völkerrecht im Bundestaat...», Op. cit. p. 33; BAYER, H.-W. Die Bundestreue..., Op.cit. p. 18; SCHNEIDER, Hans (1957). «Staatsverträge und Verwaltungsabkommen zwischen deutschen Bundesländern», Zeitschrift für Öffentliches Recht und Verwaltungswissenschaften, núm. 10, p. 649.

169 LAMMERS, H.-H./SIMONS, W. Die Rechtssprechung..., vol. I, Op. cit. pp. 207 y ss.

170 Ibid. p. 210.

171 Ibid. p. 207.

172 Ibid.

173 GRUND, Henning (1976). Preussenschlag im Jahre 1932, Baden-Baden, Editorial Nomos, p. 9; BRACHER, Karl Dietrich (1971). Die Auflösung der Weimarer Republik: Eine Studie zum Problem des Machtverfalls in der Demokratie, 5. edición, Villingen, Editorial Ring, p. 557; VETTER, Joachim (1979). Die Bundestaatlichkeit in der Rechtssprechung des Staatsgerichtshofs der Weimarer Republik, Baden-Baden, Editorial Nomos, pp. 126 y ss.; STERN, K. «Die geschichtlichen Grundlagen...», Op.cit. pp. 705 y ss.

174 Decreto del Presidente del Reich sobre el restablecimiento de la seguridad pública y el orden en el territorio del Estado de Prusia del 20 de julio de 1932, Boletín de Leyes Imperiales, 1932 I, p. 377. 
comisarios del Reich designados por él. El gobierno de Prusia demandó las medidas del Reich ante el Tribunal del Estado cuestionando la legitimidad de la aplicación del art. 48 I y II CRW. ${ }^{175}$

Según el Reich debido a las circunstancias políticas específicas en julio de 1932, para mantener la seguridad y el orden público se cumplían los requisitos del art. 48 II CRW. Admitió cumplir con los requisitos de la ejecución del Reich según el art. 48 I CRW, por el que el Presidente del Reich usó la fuerza armada para persuadir al Land por no cumplir con sus obligaciones. ${ }^{176}$ Según el Reich el incumplimiento del deber de Prusia en base al art. 48 I CRW consistió, en el hecho de que Prusia no garantizaba la seguridad pública y el orden, y además Prusia violó «el deber de lealtad» al Reich. ${ }^{177}$ A este respecto, el Reich se refirió a las declaraciones del Ministro de interior de Prusia SEVERING, que criticaba el Gobierno del Reich con una actitud vacilante en la lucha contra el movimiento comunista. ${ }^{178}$

Por su parte, el gobierno prusiano consideró la acción unilateral del Reich como un desprecio a la obligación del deber de «comportarse de forma favorable al gobierno federal». ${ }^{179}$ El Reich acusó a la Prusia de violar su deber de lealtad, ignorando que el Reich también tenía obligaciones federales de lealtad con cada Land. ${ }^{180}$ En concreto, el gobierno prusiano argumentó que no había recibido ninguna comunicación de no haber cumplido con alguna obligación imperial. Su comportamiento fue extremadamente leal ${ }^{181}$ en todo momento. Por lo tanto, el incumplimiento de los derechos alegados por el Reich en el sentido del artículo 48 I CRW no quedó justificado ni probado. $^{182}$

En la parte oral del proceso tomaron parte importantes representantes del Derecho Público alemán. ${ }^{183}$ En sus comentarios sobre el art. 48 I CRW dejaron claro que,

175 GRUND, H. Preussenschlag und Staatsgerichthof..., Op. cit. pp. 13 y ss.; BRACHER, K.D. Die Auflösung der Weimarer Republik..., Op.cit. p. 501.

176 BAYER, H.-W. Die Bundestreue..., Op.cit. p. 15 y ss.; POETZSCH, Fritz (1925). «Vom Staatsleben unter der Weimarer Verfassung», Jabrbuch des öffentlichen Rechts der Gegenwart, núm. 13, pp. 96 y ss.

177 LAMMERS, H.-H./SIMONS, W. Die Rechtssprechung..., vol. I, Op.cit. p. 38.

178 GRUND, H. Preussenschlag und Staatsgerichthof..., Op.cit. pp. 118 y ss.; VETTER, J. Die Bundestaatlichkeit..., Op.cit. pp. 127 y ss.

179 LAMMERS, H.-H./SIMONS, W. Die Rechtssprechung..., vol. V, Op.cit. p. 40.

180 PETERS, Hans (1933). Preussen contra Reich vor dem Staatsgerichtsthof: Stenogrammbericht der Verhandlungen vor dem Staatsgerichstshofin Leipzig vom 10. bis. 14 und vom 17. Oktober 1932 [Prussia v. Reich before the court: Stenographic report of the proceedings before the court in Leipzig, 10 to 14 and 17 October 1932]. Glashütten im Taunus: Editorial Detlev Auvermann, p. 170.

181 BRECHT, D. Preussen contra Reich ... Op.cit. p. 396.

182 LAMMERS, H.-H./SIMONS, W. Die Rechtssprechung..., vol. V, Op. cit. p. 39; BRECHT, D. Preussen contra Reich ... Op.cit. pp. 399 y ss.

183 Los siguientes actuaron a favor del Reich: BILFINGER, C., JACOBI, E., SCHMITT, C. Mientras que a favor de Prusia y sus contemporáneos actuaron: ANSCHÜTZ, G., GIESE, F., HELLER, H., MAUNZ, T., NAWIASKY, H., PETERS, H., STERN, K. «Die geschichtlichen Grundlagen...», Op.cit. p. 706; HUBER, E.R. Preussen contra Reich ...Op.cit. p. 3. 
los deberes del Land se derivan no solo de la constitución escrita y las leyes del imperio, sino también del deber general de lealtad del Land al Reich. ${ }^{184}$

BILFINGER afirmó sobre la fórmula del art. 48 I CRW también abarcaba un aspecto «que se conocía desde mucho tiempo en la literatura jurídica: la idea del deber de lealtad». ${ }^{185}$ Además, esta obligación no se limitaba solamente los Länder frente al Reich, sino que era una obligación mutua. En este sentido, NAWIASKY enfatizó que en caso de divergencias el Reich debía de actuar hacia los Länder de la misma manera que lo hacía con los estados extranjeros. ${ }^{186} \mathrm{Si}$ tal obligación existiera en el Derecho Internacional Público en un Land sería aún «más obligación», en la que las partes dependían unas de otras. Solo su unión daría como resultado la totalidad del Reich. Para NAWIASKY, sin esta obligación mutua de las dos partes, la construcción de Estado Federal carecía de sentido. ${ }^{187}$

El Tribunal del Estado en la sentencia del 25 de octubre de 1932 aceptó la posibilidad de que los Länder violaran sus obligaciones imperiales. Con ello, respaldó la opinión sobre la existencia de un deber de lealtad en las relaciones entre el Reich y los Länder. ${ }^{188}$

El Tribunal de Estado se pronunció sobre los argumentos de partido en relación con el Art. 48 I CRW. En primer lugar, el tribunal admitió que en momentos de mucha crispación y enfrentamiento político los ataques de Ministros al Reich podían ser considerados como una vulneración del principio de lealtad al Imperio. Sin embargo, después de examinar las declaraciones del Ministro de Prusia SEVERING reconoció que no excedían los límites, de tal manera que no podía considerarse como una violación del deber de lealtad de un Land hacia el Reich. ${ }^{189}$

El Tribunal continuó alegando que el movimiento comunista no fue combatido lo suficiente, pero dado que no se aclaró si el motivo fue una debilidad ante los comunistas, el Tribunal no pudo constatar la violación del deber en el sentido del art. 48 I CRW. Por lo tanto, las medidas adoptadas por el Reich contra Prusia no pudieron basarse en el art. 48 I CRW. ${ }^{190}$ Sin embargo, el Tribunal del Estado consideró legitimo el procedimiento en relación a los poderes del Presidente del Reich en base al art. 48 II CRW, porque en su opinión, las medidas se tomaron ante graves perturbaciones y amenaza de la seguridad pública. Pero, la Alta Corte de Justicia objetó sobre la extensión y el alcance de los poderes otorgados por el decreto al canciller. ${ }^{191}$ Como

184 PETERS, H. Preussen contra Reich ... Op.cit. p. 140; HELLER, H. Preussen contra Reich ... Op.cit. p. 169.

BILFINGER, C. Preussen contra Reich ... Op.cit. p. 150.

NAWIASKY, H. Preussen contra Reich ...Op.cit. p. 173.

187 Ibid.

188 EGLI, P. Die Bundestreue..., Op.cit. p. 56.

189 LAMMERS, H.-H./SIMONS, W. Die Rechtssprechung..., vol. V, Op.cit. p. 58.

190 Ibid. p. 59; LAMMERS, H.-H./SIMONS, W. Preussen contra Reich ...Op.cit. p. 513; VETTER, J. Die Bundestaatlichkeit..., Op.cit. pp. 132 y ss.

191 LAMMERS, H.-H./SIMONS, W. Die Rechtspprechung..., vol. V, Op. cit. pp. 60 y ss.; LAMMERS, H.-H./SIMONS, W. Preussen contra Reich ... Op.cit. pp. 513 y ss.; VETTER, J. Die 
resultado, el Tribunal del Estado reconoció un deber de lealtad al Reich basado en el Derecho Constitucional no escrito, que cuya observancia podía ser reclamada a través de la ejecución del Reich (art. 48 I CRW). ${ }^{192}$

En términos de contenido el deber de lealtad incluía el respeto hacia la política del Reich por parte de un gobierno de un Land y sus miembros, incluso cuando éstos no actuaban oficialmente. Sin embargo, no todas las declaraciones constituían una violación, sino solo tenían consecuencias los casos difíciles y en situaciones de tensiones políticas graves. Según el Tribunal del Estado se debía de demostrar que existía un incumplimiento subjetivo del deber de lealtad. ${ }^{193}$ Mediante el caso «Preussenschlag» el Tribunal reconoció explícitamente la obligación de lealtad federal de los Länder frente el Reich. Por el contrario, el alto Tribunal no entró a juzgar sobre la idea de la obligación de lealtad federal del Reich sobre los Länder.

Otras sentencias posteriores mostraron que el Reich también estaba obligado a la lealtad federal; ${ }^{194}$ es el caso sobre a las expropiaciones de los ferrocarriles del Reich de 30 de junio 1923 (Reichseisenbabn). Entre sus consideraciones, el Reich en el ejercicio de su competencia exclusiva de expropiación sobre los ferrocarriles del Reich estaba obligado a salvaguardar y respetar los intereses de los Länder. ${ }^{195}$ De modo que el Ministro de transporte del Reich tenía un enorme poder a usar unilateralmente a favor los intereses del ferrocarril. Aparentemente, estas preocupaciones llevaron a que el Comité de Presupuestos del Reich creara una nueva disposición: el Ministro de Transporte antes de tomar una decisión sobre expropiaciones ferroviarias debía escuchar a las autoridades policiales del Land. ${ }^{196}$ En opinión del Tribunal del Estado la disposición cuadraba plenamente con el significado de la Constitución de 1919. Al parecer, el Reich mediante el art. 90 CRW había logrado, por un lado, un equilibrio justo entre los intereses de la política y la tecnología ferroviaria, y por otro, la policía de los Länder. ${ }^{197}$

De acuerdo con la jurisprudencia del Tribunal del Estado se llegó a la conclusión de que el Reich a la hora de ejercer sus competencias exclusivas, debía de tener en cuenta los intereses de los Länder para con ello llegar a la mejor solución posible para todas las partes. ${ }^{198}$

Bundestaatlichkeit..., Op.cit. pp. 140 y ss; GRUND, H. Preussenschlag und Staatsgerichthof..., Op.cit. pp. 142 y ss.

192 BAUER, H. Die Bundestreue..., Op.cit. p. 97; GRUND, H. Preussenschlag und Staatsgerichthof..., Op.cit. p. 119; VETTER, J. Die Bundestaatlichkeit..., Op.cit. pp. 137 y 157.

193 VETTER, J. Die Bundestaatlichkeit..., Op.cit. 139 y 157.

194 EGLI, P. Die Bundestreue..., Op.cit. p. 58.

195 LAMMERS, H.-H./SIMONS, W. Die Rechtssprechung..., vol. I, Op. cit. pp. 43 y ss.

196 Ibid. pp. 55 y ss.

197 Ibid. pp. 56.

198 Vid. VETTER, J. Die Bundestaatlichkeit..., Op.cit. pp. 157 y ss.

N. ${ }^{\circ} 109$, septiembre-diciembre 2020, págs. 261-294 


\section{CONCLUSIÓN}

La tradición del principio de la lealtad federal (Bundestreue) se remonta al Reich alemán de $1871 .{ }^{199}$ Desde su origen hasta hoy la aportación del Rudolf SMEND considerado como el "padre» científico jurídico de la idea - ha sido decisiva para su comprensión. ${ }^{200}$ En su obra de 1916, ${ }^{201}$ «Derecho Constitucional no escrito en el Estado Federal Monárquico,» definió el fundamento normativo del principio como una la ley constitucional no escrita. Además de dotar de fuerza normativa a las prácticas políticas del canciller BISMARCK, logró adaptar su doctrina científica a las diferentes épocas: desde el Estado monárquico basado en «individualidades estatales históricamente legítimas», pasando por la República de Weimar hasta nuestros días mediante la jurisprudencia del Tribunal Constitucional Federal.

Según SMEND, los deberes de lealtad se derivaban de una relación de cooperación de la Federación con sus aliados. Se trataba de un pacto entre principados con base contractual en virtud de tratados, cuya soberanía no emana de la totalidad de la nación, sino de la voluntad de los Estados soberanos. La idea del Bundestreue ayudaba a complementar los vacíos legales del Derecho Constitucional escrito como solución adecuada a cada caso. ${ }^{202}$

Sin embargo, bajo la Constitución de Weimar ya no era posible establecer una conexión con los fundamentos contractuales del Estado federal, ya que ésta se fundamentaba directamente con la Asamblea Nacional Alemana. ${ }^{203}$ Aunque la referencia en el preámbulo al "pueblo alemán» no servía como punto de partida para la lealtad federal, en otros apartados de la Constitución había disposiciones relacionadas, que creaban obligaciones a concretar en tres grupos: a) obligaciones de respeto mutuo, b) obligación de solución pacífica de disputas, y c) obligaciones de información, consulta y participación.

Después de que el principio perdiera completamente su importancia durante el nacionalsocialismo, ${ }^{204}$ su existencia se revalorizó bajo la Ley Fundamental de Bonn mediante los pronunciamientos del TCF, el cual apoyó la recepción de este concepto en sus raíces históricas y doctrinales. ${ }^{205}$ Debido a la escasez de materiales en el idioma español, este estudio ha querido realizar una contribución de acercamiento histórico al Bundestreue.

199 Vid. BAUER, H. Die Bundestreue..., Op.cit. p. 38 y ss.

200 Vid. BICKENBACH, Christian (2005). «Rudolf Smend (15. Januar 1882 bis 5. Juli 1975) Grundzüge der Integrationslehre», Zeitschrift für Studium und Referendariat, núm. 7, pp. 588 y ss.

201 SMEND, R. Staatsrechtliche Abhandlungen ..., Op.cit. p. 51.

202 SMEND, R. Staatsrechtliche Abhandlungen ..., Op.cit. p. 56.

203 ANSCHÜTZ, G. Die Verfassung..., op.cit., pp. 31 y ss.; HUBER, E.R. «Die Weimarer Reichsverfassung»..., Op.cit. p. 5.

204 Vid. UNRUH, P. «Die Unionstreue...», pp. 41 y 50; BAYER, H-W. Die Bundestreue..., Op.cit. p. 26.

205 LASO PEREZ, J.J. «La Lealtad Federal...», op. cit. p. 60. 
En definitiva desde sus orígenes se aprecia que del principio de la lealtad federal origina un efecto tridimensional, que vincula y obliga a todos los miembros del Estado, del que derivan amplias consecuencias jurídicas cuya formulación hoy obliga también a la judicatura.

Title:

The historical development of the principle of federal loyalty in german law.

\section{Summary:}

1. Introduction. 2. The origin of the principle of federal loyalty in the Second Reich of 1871. 2.1. The formation of the Second German Reich: the Constitution of 1871. 2.2. Federal Council (Bundesrat): as «court» for the resolution of conflicts (art. 76 I CR). 2.3. The first dogmatic approaches: TRIEPEL and LABAND. 2.4. The dogmatic foundation of SMEND in his work «Unwritten Constitutional Law in the Monarchical Federal State». 2.5. Subsequent doctrinal contributions: ANSCHÜTZ, TRIEPEL and KAUFMANN. 3. The principle of federal loyalty in the Weimar Republic. 3.1. The birth of the Republic: the Constitution of 1919. 3.2. Specification of the principle of federal loyalty in the Weimar Constitution. 3.3. Dogmatic foundation of the Bundestreue in the Weimar Republic. 3.4. Jurisprudence on the Bundetrene in the Weimar Republic. 4. Conclusion.

\section{Resumen:}

El «padre» del principio de la lealtad federal - Rudolf SMEND - ha pasado a la historia por su aportación en la obra «Derecho Constitucional no escrito en el Estado Federal Monárquico.» Por primera vez en la historia del constitucionalismo alemán y en contra de la doctrina constitucionalista del Imperio de 1871, presentó y analizó el principio lealtad federal de forma jurídica y sistemática dotándolo de fuerza normativa. Aunque originariamente fue desarrollado para el contexto de una monarquía constitucional, lo fue adaptando a las diferentes épocas y formas de Estado. Por ello, desde el punto de vista histórico los enfoques bajo la Constitución del Imperio Alemán de 1871 y Constitución Republicana de Weimar de 1919 son de suma importancia. Muestra de ello es que el Tribunal Constitucional Federal Alemán en sus más tempranos pronunciamientos sobre la lealtad federal (ej.: STCF 1, 299; 12, 205) hace explícita referencia a la 
obra de SMEND. En concreto, son sentencias sobre el principio fundadas en las «profundas raíces dogmáticas e históricas» del ordenamiento alemán. Por ello, todavía hoy las posturas doctrinales sobre el principio del Bundestreue en las fases iniciales de formación del Estado alemán son de decisiva importancia. En el caso español los trabajos sobre el desarrollo histórico de este principio destacan por su ausencia. Carencia que dificulta entender su significado y alcance. Ha sido precisamente el objetivo de este trabajo el llenar este vacío.

\begin{abstract}
:
The «father» of the principle of federal loyalty - Rudolf SMEND - has gone down in history for his contribution to the work «Unwritten Constitutional Law in the Monarchical Federal State». For the first time in the history of German constitutionalism, and contrary to the constitutional doctrine of the Empire of 1871, he presented and analyzed the federal loyalty principle in a legal and systematic way endowing it with normative force. Although it was originally developed for the context of a constitutional monarchy, it was adapted to different times and forms of State. Therefore, from a historical point of view, the approaches given in the Constitution of the German Empire of 1871 and the Republican Constitution of Weimar of 1919 are of utmost importance. Proof of this is that the German Federal Constitutional Court in its earliest pronouncements on federal loyalty make explicit reference to the work of SMEND (ex.: BVerfGE 1, 299; 12, 205). Specifically, they are judgments on the principle founded on the «deep dogmatic and historical roots» of the German order. Therefore, even today the doctrinal positions on the Bundestreue principle in the initial stages of the formation of the German State are of decisive importance. In the Spanish case, the works on the historical development of this principle stand out for their absence. Lack that makes it difficult to understand its meaning and scope. It has been precisely the objective of this work to fill this gap.
\end{abstract}

Palabras clave:

Lealtad federal; Derecho Constitucional no escrito; Imperio; Obligaciones; Bundesrat.

Keywords:

Federal loyalty; unwritten Constitutional law; Empire; obligations; Bundesrat. 